Direction des acquisitions et

des services bibliographiques

395, rue Wellington

Ottawa (Ontario)

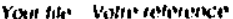

NOTICE

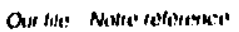

AVIS

The quality of this microform is heavily dependent upon the quality of the original thesis submitted for microfilming. Every effort has been made to ensure the highest quality of reproduction possible.

If pages are missing, contact the university which granted the degree.

Some pages may have indistinct print especially if the original pages were typed with a poor typewriter ribbon or if the university sent us an inferior photocopy.

Reproduction in full or in part of this microform is governed by the Canadian Copyright Act, R.S.C. 1970, c. C-30, and subsequent amendments.
La qualité de cette microforme dépend grandement de la qualité de la thèse soumise au microfilmage. Nous avons tout fait pour assurer une qualité supérieure de reproduction.

S'il manque des pages, veuillez communiquer avec l'université qui a conféré le grade.

La qualité d'impression de certaines pages peut laisser à désirer, surtout si les pages originales ont été dactylographiées à l'aide d'un ruban usé ou si l'université nous a fait parvenir une photocopie de qualité inférieure.

La reproduction, même partielle, de cette microforme est soumise à la Loi canadienne sur le droit d'auteur, SRC 1970, c. C-30, et ses amendements subséquents. 


\title{
INDUCIBLE IMMUNITY TO TRICHOMONAS VAGINALIS \\ IN A MOUSE MODEL OF VAGINAL INFECTION
}

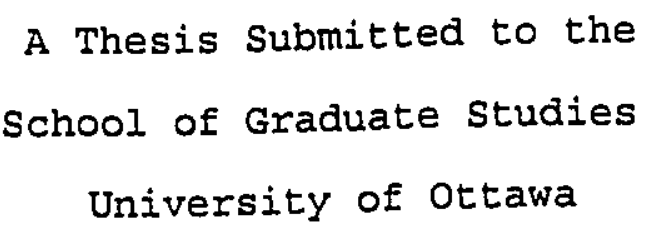

In Partial Fulfillment of the Requirements for the Degree of

\author{
Master of Science \\ Department of Microbiology and Immunology \\ Faculty of Medicine
}

By

Mary Cherian Abraham

(C) Mary Cherian Abraham, Ottawa, Canada, 1995 
National Library

of Canarja

Acquisitions and

Bibliographic Services Branch

395 Wellington Street

Ottawa, Ontario

K1A ON4
Bibliothèque nationale

du Canada

Direction des acquisitions et

des services bibliographiques

395. rue Wellington

Oltawa (Ontario) rous tite volio taterence

Our tile Nolie solderence
The author has granted an irrevocable non-exclusive licence allowing the National Library of Canada to reproduce, loan, distribute or sell copies of his/her thesis by any means and in any form or format, making this thesis available to interested persons.
L'auteur a accordé une licence irrévocable et non exclusive permettant à la Bibliothèque nationale du Canada de reproduire, prêter, distribuer ou vendre des copies de sa thèse de quelque manière et sous quelque forme que ce soit pour mettre des exemplaires de cette thèse à la disposition des personnes intéressées.
The author retains ownership of the copyright in his/her thesis. Neither the thesis nor substantial extracts from it may be prinied or otherwise reproduced without his/her permission.
L'auteur conserve la propriété du droit d'auteur qui protège sa thèse. Ni la thèse ni des extraits substantiels de celle-ci ne doivent être imprimés ou autrement reproduits sans son autorisation.

ISBN $\quad 0-612-07871-X$ 


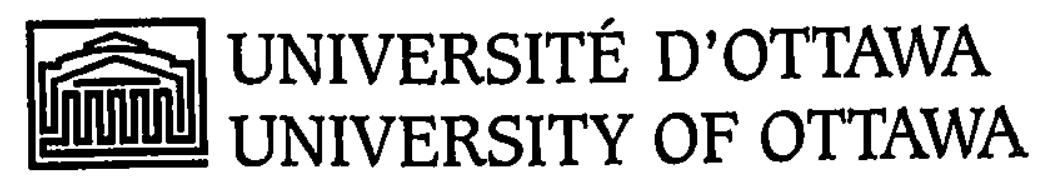




\section{ABSTRACT}

Trichomonas vaginalis is a protozoan parasite that causes a common sexually transmitted disease, trichomoniasis. Despite its high prevalance, the pathogenesis and immunogenicily of $T$. vaginalis are not well understood. Because currently available therapies are not always effective in treatment or in disease control and because of the impact of $T$.vaginalis on the health of women, a vaccination strategy could be an effective method of prevention. We studied the protective effects of subcutaneous immunization with $T$.vaginalis using a mouse model of vaginal infection. Balb/c mice were either immunized with T.vaginalis suspended in Freund's complete adjuvant (FCA) at day -56 and boosted with Freund's incomplete adjuvant (FIA) at day -28 , or immunized only at day -28 with either TV/FCA or TV/FIA. Control mice were sham immunized and boosted with phosphate-buffered saline suspended in FCA and FIA respectively. At day 0 all mice were. intravaginally inoculated with T.vaginalis. Mice immunized and boosted had significantly less intravaginal infection and had an elevated serum and vaginal antibody response compared to single immunization or control mice. Immunization with whole $T$.vaginalis appears to confer protection against intravaginal challenge with $T$.vaginalis in this animal model of infection. 


\section{ACKRNOWLEDGEMENTS}

I owe my grateful thanks to Dr. G.Garber for encouraging me to undertake this work and ensuring its successful completion. His guidance and optimism are greatly appreciated. Thanks are also extended to members of my thesis advisory committee, Drs. W. Cameron, L. Filion and $w$. Toye for their kind guidance and sound advice throughout this project and for numerous suggestions in writing this thesis.

I would also like to thank the ACSS staff, especially G. Diotte for all the technical help and for the use of their facilities.

Finally, I wish to thank M. Desjardins and K.C. Meysick for their generous support and encouragement, and their invaluable help throughout the period of this work.

A special thaniks also goes to my husband Benny for his genuine interest and continual support in this, and all my endeavors.

This thesis is dedicated to my mother. 
TABLE OF CONTENTS

PAGE

ABSTRACT .........................

ACKNOWLEDGEMENTS ...................... ii

TABLE OF CONTENTS...................... iii

LIST OF FIGURES ...................... v

LIST OF TABLES ...................... vii

LIST OF ABBREVIATIONS................... viii INTRODUCTION

TRICHOMONAS VAGINALIS $\ldots \ldots \ldots \ldots \ldots \ldots \ldots \ldots \ldots \ldots \ldots \ldots \ldots \ldots$

ANIMAL MODELS OF $\underline{T}$. VAGINALIS INFECTION .......... 15

IMMUNOLOGIC ASPECTS OF TRICHOMONIASIS........... 17

RATIONALE ......................... 29

oвJECTIVES ........................ 32

MATERIALS AND METHODS

STRAINS .......................... 33

INTRAVAGINAL INOCULATION OF MICE............ 34

IMMUNIZATION EXPERIMENTS ............... 36

RE-INFECTION EXPERIMENTS IN METRONIDAZOLE

TREATED T. VAGINALIS INFECTED MICE............ 41

MOUSE VAgINAL WASHES AND TAIL BLEEDS........... 43

ENZYME LINKED IMMUNOSORBENT ASSAY (ELISA) . . . . . . 44

STATISTICAL ANALYSIS.................. 46

ANIMAL CARE ........................ 46 


\section{RESULTS}

OPTIMIZATION OF ELISA.................. 47

OPTIMUM INOCULATION SIZE OF $\underline{T}$.VAGINALIS

FOR IMMUNIZATION. .................... 47

IMMUNIZATION REGIMEN OF $\mathrm{T}$. VAGINALIS $\ldots \ldots \ldots \ldots \ldots \ldots$

IMPORTANCE OF BOOSTING ................. 65

METRONIDAZOLE TREATMENT \& RE-INFECTION............ 73

DISCUSSION

IMMUNIZATION WITH T.VAGINALIS IN OUR MOUSE

MODEL OF INFECTION ..................... 75

SIZE OF INOCULATION TO T.VAGINALIS

FOR IMMUNIZATION. .................... 76

IMMUNIZATION REGIMEN AND ROLE OF ADJUVANT.......... 77

MULTIPLE IMMUNIZATION ON PROTECTION............ 83

Conchusion $\ldots \ldots \ldots \ldots \ldots \ldots \ldots \ldots \ldots \ldots \ldots \ldots$

LIST OF REFERENCES .................... 89

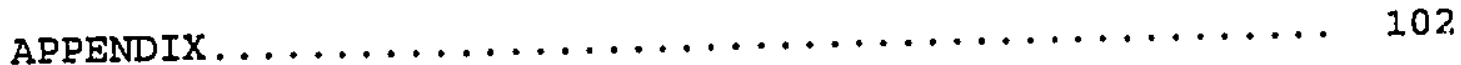




\section{LIST OF FIGURES}

1. Mouse anti-T.vaginalis standard curve......... 48

2. Optimum inoculation size of $T$.vaginalis for Immunization: Survival analysis............ 53

3. Optimum inoculation size of T.vaginalis for immunization: Kinetics of IgG serologic response

to $T$.vaginalis upon immunization and infection.....

4. Optimum inoculation size of $T$.vaginalis for Immunization: Kinetics of vaginal IgG response to $T$. vaginalis upon infection.............. 55

5. Optimum inoculation size of T.vaginalis for immunization: Kinetics of vaginal IgA response to $T$.vaginalis upon infection.............. 56

6. Immunization regimens and role of adjuvant:

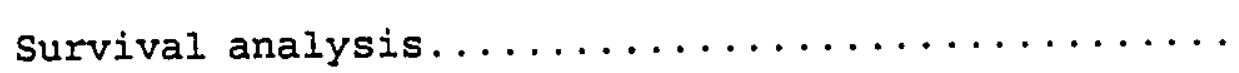

7. Immunization regimens and role of adjuvant:

Kinetics of IgG serologic response

to $T$. vaginalis upon immunization and infection..... 62

8. Immunization regimens and role of adjuvant:

Kinetics of vaginal IgG response

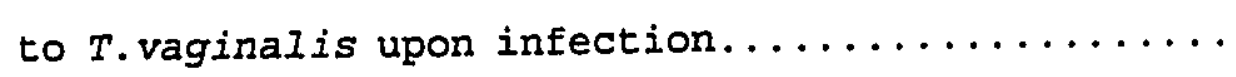

9. Immunization regimens and role of adjuvant:

Kinetics of vaginal IgA response

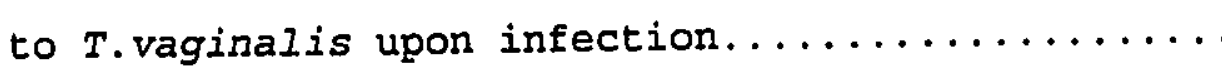


10. Multiple immunization and protection:

Survival analysis...................... 69

11. Multiple immunization and protection:

Kinetics of IgG serologic response

to $T$.vaginalis upon immunization and infection.... 70

i2. Multiple immunization and protection:

Kinetics of vaginal IgG response

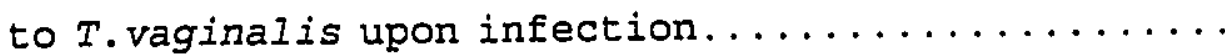

13. Multiple immunization and prctection:

Kinetics of vaginal IgA response

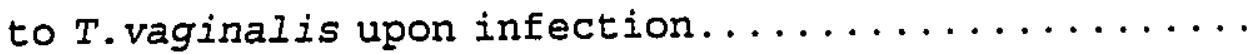




\section{IIST OF TABLES}

1. Dosage optimization................. 38

2. Immunization regimen and role of adjuvant........ 39

3. Role of multiple immunization............... 40

4. Does vaginal infection and treatment induce protection..................... 42

5. Optimum inoculation size of $\underline{T}$. vaginalis

For immunization..................... 52

6. Immunization regimen and role of adjuvant....... 60

7. Multiple immunization on protection.......... 68

8. Metronidazole treatment and protection.......... 74 


\section{IIST OF ABBREVIATIONS}

\begin{tabular}{|c|c|}
\hline ABTS & 2.2'-Azino-di-[3-athyl-benzthiazolinsulfonate (6)] \\
\hline CDF & Cell-detaching factor. \\
\hline CPE & Cytopathic effects. \\
\hline ELISA & Enzyme linked immunosorbent assay. \\
\hline FBS & Fetal bovine serum \\
\hline FCA & Freund's complete adjuvant \\
\hline FIA & Freund's incomplete adjuvant. \\
\hline HIV & Human immunodeficiency virus. \\
\hline IgA & Immunoglobulin class A \\
\hline IgG & Immunoglobulin class $\mathrm{G}$ \\
\hline IgM & Immunoglobulin class $M$ \\
\hline La & Lactobacillus acidophilus. \\
\hline MRS & Lactobacillus MRS broth \\
\hline NBCS & Newborn calf serum \\
\hline PBS & Phosphate buffered saline. \\
\hline PMN & Polymorphonuclear neutrophils \\
\hline STD & Sexually transimitted disease. \\
\hline SDS & Sodium dodecyl sulphate \\
\hline Sc & Subcutaneous immunization \\
\hline TV & Trichomonas vaginalis \\
\hline TYI & Diamond TYI-S-33 medium \\
\hline ug & Microgram \\
\hline um & Micrometer \\
\hline
\end{tabular}




\section{INTRODUCTIION}

TRICHOMONAS VAGINALIS:

GENERAI BACKGROUND

Trichomonas vaginalis, the causative agent of sexually transmitted trichomoniasis throughout the world, was first described by Donne in 1836. This flagellated trophozoite protozoan parasite belongs to the family Trichomonadidae. $T$. vaginalis is the only pathogenic member of the three trichomonad species ( $T$.hominis, T.tenax, and $T$.vaginalis) that parasitize humans, and it inhabits the genito-urinary system (Brown 1972; Honigberg 1978; Jirovec and Petru 1968).

T. vaginalis is a pleomorphic organism and environmental conditions appear to affect its morphology. The morphology of this parasite is often variable in living, and in fixed stained preparations as well as with varying physicochemical conditions (Honigberg 1978). In axenic cultures, such as in Diamonds- TYI medium, the organism appears pear-shaped or ovoid, ranging in size from 10-30 um, with four anterior flagella, an undulating membrane and a long axostyle, which bisects the cell longitudinally, protruding through the posterior end (Jirovec and Petru 1968; Honigberg 1978; Lossick and Kent 1991; Heine and McGregor 1993). The motion of the 
Elagella and the undulating membrane gives $T$. vaginalis its characteristic jerky, non-directional movement. T.vaginalis has a large nucleus, characteristic of other eukaryotic cells, a highly developed golgi complex (Heine and McGregor 1993) but lacks mitochondria and can exist in anaerobic conditions (Krieger 1981; Muller 1990).

For many decades, T. vaginalis was thought to be a commensal of the urogenital tract. However, now its role as a pathogen of the human urogenital tract is undisputed. The reasons why this protozoan deserves renewed and increased attention in biomedical research are numerous. Trichomoniasis is an important sexually transmitted disease (STD) of world wide distribution. It has been estimated that annually, 5 million women in the United States (Jarecki-Black et al., 1988) and 180 million women worldwide are infected with T.vaginalis. (Brown 1972; Thomson and Gelbert 1989). Despite the prevalence of $T$.vaginalis infection, its pathogenic mechanisms have not been well characterised. Trichomoniasis is not a selElimitting disease and the extent and nature of sequelae remain largely undefined (Alderete 1987). T.vaginalis in women has been associated with an increased incidence of low birth weight, (Cotch 1991; Lossick and Kent 1991) premature rupture of membranes (Draper et al., 1991; Heine and McGregor 1993; Lossick and Kent 1991), premature delivery and post-partum endometritis (Cotch 1991; Heine and McGregor 1993). In vitro 
studies of Draper et al. (1991) support the observations on the ability of $T$.vaginalis to rupture amniotic membranes. Association of $T$. vaginalis with an increased predisposition to HIV infection has already been documented (Laga et al., 1993; 1994).

The clinical presentation of trichomoniasis ranges from. acute to asymptomatic infection. Nearly 50\% of the women harboring this parasite are asymptomatic (Krieger 1981) with one-third of them developing frank vaginitis within six months (Rein 1990; wolner-Hansen et al., 1989). How the clinical presentation of the disease can vary from a totally asymptomatic vaginal infection to florid vaginitis is not clear. T. vaginalis primarly infects the mucosal squamous epithelium of the urogenital tract (Nielsen and Nielsen 1975) occuring both intravaginally and extravaginally in women (Wallin et al., 1981).

It is not known whether inflammatory response seen in trichomoniasis is due to close contact between $T$.vaginalis and the vaginal epithelium, due to cellular products secreted by the organisms, due to the host response to mucosal infection, or a combination of factors. T.vaginalis causes a cytotoxic effect on cell culture monolayers, and this effect is dependent upon the inoculum size and length of time that T.vaginalis is in contact with the monolayer (Alderete and 
Pearlman 1984; Garber et al., 1987; Garber et al., 1989a; Krieger et al., 1984). Garber et al. (1989a) demonstrated the presence of a secretable cytotoxin or cell detaching factor (CDF) of T.vaginalis. This detaching factor causes a cytopathic effect (CPE) with disruption of the cell culture monolayer in a similar manner to the effects seen when T.vaginalis is in direct contact with the monolayer. Aside from CDF, multiple proteases have been found in cell lysates of T.vaginalis (Coombs and North 1983; Lockwood et al., 1984). Protease activity has been implicated as having a role in T.vaginalis adherance to epithelial cells (Arroyo and Alderete 1989), suggesting a role of protease in pathogenesis. Garber and Lemchuk-Favel (1989b) were able to isolate two extracellular cysteine proteases from the cell free filtrate of T.vaginalis. Very recently, Provenzano and Alderete (1995) proposed the potential role of $T$.vaginalis cysteine proteases in degrading secretory immunoglobulins as well as their role in enhancing the infection rate and pathogenicity of other concomitent coinfecting STD pathogens, including HIV. Factors in the vaginal microenvironment including menstrual blood, $\mathrm{pH}$, oxidation-reduction potential, hormonal levels and other microbes may be associated with pathogenicity. 


\section{CLINICAI RRESENTATION:}

In women, the most common complaint associated with trichomoniasis and an acute inflammatory response, is a heavy vaginal discharge and vulvovaginal irritation (Fouts and Kraus 1980; Rein 1990). Vaginal and cervical erythema, also termed "strawberry cervix" is noted in many patients (Rein 1990; Wolner-Hanssen 1989). As mentioned previously, T.vaginalis has also been associated with increased prenatal morbidity.

$T$. vaginalis is also found in men even though it seems to be more often asymptomatic. In chronic cases there may be a slight itching sensation and purulent discharge may occasionally be observed. Purulent discharge and inflammation from the external meatus are characteristic of acute trichomonas urethritis and prostatitis (Kuberski 1978; 1980). Complications due to $T$.vaginalis infection might develop including balanoposthitis, urethral stricture, cystitis, epididymitis and sterility (Jarecki-Black et al., 1988; Paulson et al., 1985; Tuttle et al., 1977). Non-gonococcal urethritis is the most common clinical symptom associated with T.vaginalis infection in men (Kreiger 1990; Kuberski 1980).

\section{TRANSMISSION :}

It is widely accepted that $T$.vaginalis is transmitted by 
sexual intercourse (Kreiger 1990; Rein 1990) and there are very few documented cases of other modes of transmission. Neonatal trichomoniasis is acquired during vaginal delivery (Bramley 1976; Neistein et al., 1984; Kurnatowska 1990) and has been reported in about 5 percent of female babies born to infected mothers (Neistein et al., 1984; Mclaren et al.. 1983). The organism is sensitive to desiccation and survives. in various body fluids such as urine, semen, vaginal exudates (Whittington 1957; Lossick 1990) or on moist objects like sponges, towels, toilet seats etc. (Whittington 1951). Such contaminated objects (fomites) may also be responsible for indirect or non-sexual transmission (Lossick 1990).

\section{DIAGNOSTS :}

Accurate diagnosis is necessary for specific treatment of trichomoniasis. Routine clinical diagnosis is dependent on microscopic identification of the parasite in wet mount preparations by characterstic morphology. Other diagnostic methods include the use of cultures and a variety of cytologic smears (Heine and McGregor 1993; Manson et al., 1976; Krieger et al., 1988).

Serological methods for diagnosis of $T$.vaginalis infection have been performed for a number of years. Serologic tests include complement fixation, precipitation, agglutination, 
hemagglutination, fluorescent antibody technique, gel diffusion, radioimmunoassay (RIA) and enzyme-linked immunosorbent assay (ELISA). These have been developed for detection of antitrichomonal antibodies in serum, vaginal secretions or semen samples (Alderete $1984 ;$ Yule et al., 1987). Polymerase chain reaction based methods in T.vaginalis diagnosis offer a high degree 'of sensitivity by the ability to amplify and detect target sequences (Rubino et al., 1991; Riley et al., 1992). Diagnosis of infeccion in asymptomatic women and men with non-gonococcal urethritis was considered a problem until Garber et al.(1987) developed a culture technique employing a McCoy cell system which could detect T.vaginalis growth with an inoculum as low as under $10^{2} / \mathrm{mL}$.

TREATMENT :

The drug of choice for treatment of trichomoniasis is metronidazole (Hager et al., 1980; Dykers 1975). Since metronidazole treatment has become available, drug resistant strains of $T$.vaginalis have emerged with variable levels of resistance (Kulda et al., 1982). Furthermore, a carcinogenic potential of metronidazole was reported based on animal studies (Speck et al., 1976; Koch et al., 1981) and mutagenic effects in bacteria (Voogd et al., 1974; Legator et al., 1975), resulting in some controversy on reservation for use in treatment. Because of the prevalence of metronidazole 
resistance and a concern regarding the safety of this drug, new control strategies such as vaccination are required to control T.vaginalis infection.

\section{INTERACTION OF T.VAGINALIS WITH OTHER MICROFLORA:}

Although $T$.vaginalis is now recognized as a significant urogenital pathogen as mentioned previously, the mechanism of its pathogenicity is not yet clearly understood. One important factor that must be taken into account in understanding the pathogenicity of $T$.vaginalis, is the role of normal microbial flora in protecting against, or facilitating infection with T.vaginalis. The vagina and its unique microflora form a finely balanced ecosystem. The harsh vaginal environment influences the microbial types present, and the microflora in turn affects the vaginal environment (Redondo-Lopez et al.. 1990). The ecosystem changes under pressure from a variety of external stimuli such as hormonal levels and fluxes, pregnancy and delivery, trauma, coitus, and birth control methods (Jorma Paavonen 1983; Larsen and Galask 1982; Mehta 1982; RedondoLopez 1990).

The vaginal flora is a dynamic and closely interrelated system, which may also be influenced by other factors such as glycogen content of epithelial cells, glucose and vaginal pH. The first extensive study of the vaginal flora was reported by 
Doderlein in 1892, who identified the prevalence of lactobacilli in the normal vaginal flora. Later qualitative and quantitative studies of the vaginal flora have demonstrated that many other facultative and obligate anaerobic organisms are present in high concentrations (Larsen and Galask 1980). Lactobacilli dominate the facultative genital tract flora as indicated by their presence in most women, being found in $70 \%$ to $96 \%$ of female patients (Larsen and Galask 1982). Various species of lactobacilli are present in the vaginal flora, and diphtheroid bacilli comprise most of the remaining facultative gram-positive rods in the female genital tract. Gram-positive cocci are the second most frequently observed bacterial morphologic forms in the normal vagina. Catalase-positive, coagulase-negative staphylococci (Staphylococcus epidermidis and Staphylococcus saprophyticus) are isolated from the vagina of $62 \%$ of healthy women. Micrococcus varians (strict aerobes), streptococcus species, and Enterococcus species are isolated from the vagina of $30 \%$ to $40 \%$ of healthy womer (Larsen and Galask 1980; 1982; Redondo-Lopez 1990). Gram-negative rods occur at low incidence with Escherichia coli most frequently isolated from the female genital tract (Jorma Paavonen 1983; Larsen and Galask 1982). Some common representatives of anaerobic organisms include gram-positive cocci (Peptococcus asaccharolyticus and Peptostreptococcus anaerobius), Lactobacillus species Bifidobacterium, Eubacterium, and Bacteroides species, 
including a low prevalance of B.fragilis (Larsen and Galask $1980 ; 1982)$. Generally, the vaginal microflora of healthy women consists of various aerobic and anaerobic bacteria, frequently dominated by lactobacillus species.

L.acidophilus is generally accepted to be the most frequently isolated lactobacillus species from the normal human vagina based on early studies. However, other studies fail to agree on which species predominate. Giorgi et al. (1987) suggested that L.cripatus, L.jensenii, L.fermentum and L.gasseri were the predominant vaginal species. This seems likely to be due to the various methods employed to identify the lactobacilli (Redondo-Lopez et al., 1990; McGroarty 1993). Research is currently applying molecular biological techniques for species identification of lactobacilli, but until these techniques are perfected and standardized, the predominant species of lactobacilli will remain controversial.

Since the first description of lactobacilli by Doderlein it has been widely assumed that lactobacilli normally present in the vagina, protect against the overgrowth of potentially pathogenic indigenous flora and exogenous pathogens. The pathogenesis of bacterial vaginosis is thought to first involve the elimination or reduction of antibacterial activity of the indigenous vaginal lactobacilli (Skarin and Sylwan 
1986; Redcado-Lopez et al., 1990). Lactobacilli inhibit the in-vitro growth of organisms associated with bacterial vaginosis including Garanerel la, Mobiluncus, Peptostreptococcus and Bacteroides species (Skarin and Sylwan 1986; Redondo-Lopez et al., 1990). There have been numerous reports of the invitro ability of lactobacilli, to inhibit the growth of potential pathogens by the release of metabolic byproducts such as fatty acids, hydrogen peroxide, hydrogen, hydroxyl ions and ammonia, as well as bacteriocins and bacteriocin-like substances (Redondo-Lopez et al., 1990; McGroarty 1993; Mardh and Soltesz 1983).

Low vaginal $\mathrm{pH}$ is believed to be a primary mechanism controlling the composition of the human vaginal microbialflora. Lactic acid and other fatty acids produced by lactobacilli contribute to the maintenance of a low vaginal $\mathrm{pH}$ which is thought to be an important control mechanism preventing colonisation by pathogenic organisms. Fatty acids produced by vaginal epithelial cells probably play a more prominent roie in maintaining the low vaginal pH (RedondoLopez et al.,1990; McGroarty 1993).

Aside from lactic acid production, lactobacilli have demonstrated the ability to excrete other compounds with antimicrobial activity including hydrogen peroxide $\left(\mathrm{H}_{2} \mathrm{O}_{2}\right)$ and inhibitory proteins (Hillier et al., 1992; Mardh 1991). In- 
vitro studies have revealed that the released $\mathrm{H}_{2} \mathrm{O}_{2}$ can be used for autoinhibition and for inhibition of adjacent microorganisms either alone or via a peroxidase-mediated system (Klebanoff et al., 1991). Inhibition of a variety of bacteria by $\mathrm{H}_{2} \mathrm{O}_{2}$ producing lactobacilli such as Salmonella typhimurium, E.coli, Clostridium perfringens (Gilliland and Speck 1977a) and L.acidophilus (Gilliland and Speck 1977 b; Klebanoff et al., 1991) have been described. In-vitro inhibition of $\mathrm{HIV}$ by high concentrations of $\mathrm{H}_{2} \mathrm{O}_{2}$ producing L.acidophilus strains and equivalent inhibition by low concentrations of L.acidophilus in combination with peroxidase and $a$ halide have been described by Klebanoff and Coombs (1991).

Bacteriocins are proteinaceous bactericidal substances produced by bacteria, with a narrow spectrum of activity, inhibiting strains of the same or closely related species. such proteinaceous inhibitors have been identified and characterised in lactobacilli (Barefoot and Klaenhammer 1984; Redondo Lopez et al., 1990). Lactobacilli are also known to produce a variety of inhibitors that broadly resemble bacteriocins but do not act against the producing strain (McGroarty 1993; Redondo-Lopez et al., 1990). Lactobacilli also adhere to uroepithelial cells and may inhibit by steric hinderance of adhesion of potential pathogens from colonising the vagina. This may constitute the protective effect of 
lactobacili.

\section{VAGINAL FLORA IN TRICHOMONIASIS:}

Although the basic vaginal flora in women has been well documented (Larsen and Galask 1982; Redondo-Lopez et al., 1990; Larsen 1993), the role of bacterial flora in genital tract infections has not been established. Understanding the role of commensal flora in pathogenicity of $T$.vaginalis, such as the mechanisms involved in colonisation may provide targets for approaches in designing effective control strategies. A predominance of lactobacilli and an acidic vaginal pH (less than 4.5) are considered part of a healthy vaginal environment (Larsen 1993). T. vaginalis has been reported to alter the normal physiological state of the human vagina drastically during infection. In trichomoniasis, the principal alterations appear to be a reduction in the lactobacillus population, a rise in anaerobic flora and an increase in vaginal $\mathrm{pH}$ to $>5.0$ (Hanna et al., 1985; Holst et al., 1987; Spiegel 1990). The mechanisms involved in.the disruption of the lactobacillus population and alteration of the vaginal flora have not yet been elucidated.

Jirovec and pertu (1968) described four stages in the development of trichomoniasis based on the severity of infection. 1) "Trichomonas acuta" is the first phase which 
occurs shortly after contact with the organism. In the vaginal secretions there are fewer epithelial cells, with the decrease in number of lactobacilli, while the trichomonads and leukocytes are increased, without significant alterations in the microflora. 2) The second phase referred to as "Culminating trichomoniasis", is characterised by numerous trichomonads and leukocytes, pleomorphic bacteria, absence of lactobacilli and the presence of few epithelial cells. 3) In "Chronic trichomoniasis", there are many epithelial cells, few leukocytes and a variety of bacteria other than lactobacilli. T.vaginalis is present in varying numbers. 4) The final phase, "Latent trichomoniasis", shows normal number of lactobacilli with many epithelial cells along with few leukocytes and trichomonads. The relevance of this classification is not known, whether there is an actual progression from stage 1 to stage 4 is still disputed. It is not known whether this progression would be controlled by virulence factors expressed by the infecting strain of T.vaginalis, by the host response or both. Furthermore, the mechanisms involved in the disruption of the lactobacillus population and alterations to the vaginal flora in general have not yet been elucidated. In this regard, an animal model may be useful to study the invivo interactions between $T$.vaginalis and the endemic vaginal flora even though, the specific features of the host-parasite interaction in animal models would differ from infections in the human genitourinary tract. An in-vivo mode? may also help 
to study the virulence markers and effects of different pathogenic strains of T.vaginalis.

\section{ANIMAI MODELS OR T.VAGINALIS INFECTION:}

Several attempts have been made at establishing an animal model for T.vaginalis infection. The laboratory mouse (Cappuccinelli et al., 1974; Coombs et al., 1986) has been the animal most widely used. Rats (Jirovec and Pertu 1968; Honigberg 1978), guinea pigs (Kazanowska 1983), hamsters (Jirovec and Pertu 1968; Honigberg 1978), and monkeys (Street et al., 1983) have also been employed. The inoculation routes most frequently used were intraperitoneal, subcutaneous, intramuscular and intravaginal. Intravaginal infection of experimental animals with $T$.vaginalis are likely to provide manifestations that are more similar to those found in human urogenital trichomoniasis. However, investigators have experienced difficulties in artificially replicating the human vagina owing to differences in hormonal control and uncharacterised differences in immune response to infectious agents.

Mice were first used for intravaginal infection by Cappuccinelli et al. (1974) and the establishment of intravaginal infection with $T$.vaginalis in mice treated with estrogens was successfully accomplished. Later, many studies 
have agreed that pretreatment of mice with estrogens is essential for establishing intravaginal infection (Meysick and Garber 1992, McGrory and Garber 1992; Coombs 1986). The vaginal epithelium is exposed to estrogen during most of the menstrual cycle in humans (Larsen 1993). T.vaginalis can settle only in an estrogenized environment (Jirovec and Petru 1968). The same study also showed that lactobacillus colonisation of the vagina is related to the estrogen effect on the vaginal epithelium. However, the factors responsible for the enhancement of infection with $T$.vaginalis in estrogenized animals are not known. The factors such as glycogen deposition on the vaginal epithelium, modification of vaginal epithelial cells, as well as changes in the normal flora and number of neutrophils (Corbeil et al., 1985) may have an indirect effect on enhancement of infection. The highest infection rate is observed when the mice are in proestrous/estrous phase when fewer neutrophils or bacteria are present in the vagina (Corbeil et al., 1985).

Meysick and Garber (1992) have studied the normal mouse vaginal flora and the effects of $T$.vaginalis infection on population dymamics. Features of host-parasite interactions in the mouse differ considerably from those of human genitourinary tract. Low prevalence of lactobacilli and neutral $\mathrm{pH}$ in the mouse vagina (Larsen et al., 1976; Skangalis et al., 1979) differ from the high carrier rates of 
lactobacilli and lower $\mathrm{pH}$ characterstic of the human vagina. In an attempt to alter the mouse vagina to parallel the situation found in the women, McGrory and Garber (1992) introduced $L$. acidophilus in the vagina of Balb/c mice prior to inoculating the mice with $T$.vaginalis. This resulted in a significantly more consistent and substained $T$.vaginalis infection. Their studies have also shown that the addition of L.acidophilus did not otherwise significantly alter the resident mouse vaginal flora. It has been well documented that trichomoniasis in women is characterized by reduction in number or total loss of lactobacilli (Jirovec and Petru 1968), which was also observed by McGrory et al. (1994).

Intravaginal infection of nonhuman primates with $T$. vaginalis may yield results that are more relavent to human trichomoniasis. Studies in squirrel monkeys (Gardner et al., 1987; Street et al., 1983) with T.vaginalis have been successful. As in the case of the mouse model, the vaginal $\mathrm{pH}$ of the squirrel monkey is neutral and the flora does not include lactobacilli. Furthermore, hormonal status of the primates appeared important in the successful establishment of infection. 
IMMONOLOGIC ASPECTS OF TRICHO\&ONIASIS:

Considering the high incidence of trichomoniasis in women in North Anerica and world wide, the knowledge of the pathogenesis and host immune responses to infection with T.vaginalis is limited. The first attempt at antigenic analysis of $T$.vaginalis were concerned with establishing the organism as a valid species, antigenically distinct from other human trichomonads (Honigberg 1970; 1978). Later work was more concerned with the demonstration of antigenic differences between different isolates of the same species. Several, groups have addressed the question of antigenic diversity of T.vaginalis and the results have shown that, each strain possesses unique antigens (Su-Lin and Honigberg 1983). Alderete and his colleagues $(1985,1986 \mathrm{a}$ and $1986 \mathrm{~b})$ studied the extent and nature of heterogeneity among representative T.vaginalis isolates and revealed that antigenic heterogeneity among $T$.vaginalis isolates is dependent upon the surface disposition of highly immunogenic protein antigens. Their data also suggested phenotypic variation among all heterogeneous isolates and also for all clones and subpopulation derived from the heterogeneous isolates. studies by Garber et al. (1986) also demonstrated the antigenic heterogeneity of T.vaginalis and showed that different individuals appear to respond immunologically to different T.vaginalis antigens. 
At present only two conclusions appear to be reasonably firmly established; 1) that T.vaginalis isolates possess a large number of common antigens and a much smaller number that are shared with other Trichomonadidae, and 2) that antibodies raised against $T$.vaginalis recognize not only common but also strain-specific antigens (Ackers 1990). Whether this represents genuine antigenic diversity or variability of immune responsiveness, and whether this phenomenon is relevant for the development of specific serodiagnostic tests, is not clear.

\section{EFFECT OF IMMONE MEDIATORS ON T.VAGINALIS IN-VITRO:}

It has long been observed that T.vaginalis and other trichomonads are lysed by normal human or animal serum (Honigberg 1970; 1978; Gillin and sher 1981). T.vaginalis activates complement by the alternative pathway as was reported by Gillin and Sher (1981). Later, Demes et al. (1987) documented that complement activated by the alternative pathway is responsible for the lysis of $T$.vaginalis in serum. The question of whether specific antibody can enhance lysis in the classic pathway is under investigation: The studies of Shaio et al.(1993) indicated that both, enhanced classical complement pathway activation and an alternative complement pathway activation facilitate T.vaginalis lysis. It has also been shown that monoclonal antibodies raised against 
$T$.vaginalis and $T$.foetus do possess effector functions, that antibody can apparently kill antigen-positive parasites in a complement-independent manner (Alderete and Kasmala 1986). To date, no evidence has been found for the direct killing of T.vaginalis organisms by cytotoxic $T$ cells. However, both macrophages and neutrophils have been shown to kill this parasite, while the effect of eosinophils has not been reported (Landolfo et al., 1980; Mantovani et al., 1981). The killing of T.vaginalis by polymorphonuclear neutrophils invitro was described by Rein et al.,(1980) and Shaio and colleagues in 1991. The process was shown to depend on the presence of oxygen and complement, but not specific antibody. The authors suggest that alternative pathway activation leads to the formation of $\mathrm{C3b}$ that binds to the surface of the parasite, which in turn leads to the binding of the parasite to neutrophils through the $\mathrm{C} 3 \mathrm{~b}$ receptors.

\section{MOMAN DEEGNSE MECHANTSMS:}

Human vaginal trichomoniasis, although it can be unpleasant and may possibly be associated with long-term side effects, is never fatal. T.vaginalis is highly site specific and occurs almost exclusively in the genital tract. However, the fact that $T$.vaginalis infection is not a systemic disease may be attributable to host defense mechanisms (Ackers, 1990). These include nonimmunologic factors, immunologic but 
nonspecific defense mechanisms, and specific immunologic responses.

NONIMUNOLOGIC HOST DEFENSE MECHANISMS:

Nonimmunologic host defense mechanisms that may protect against trichomoniasis include physical, nutritional and/or other nonimmunologic barriers. The zinc content of prostatic secretions is thought to be an important nonspecific defense against urinary tract infection in men. The antibacterial activity of the prostatic fluid of humans, dogs, and rats is proportional to its zinc concentrations (Kreiger and Rein 1982A; Fair et al., 1976; Graves and Gardner 1993; Heine and MCGregor 1993). In the case of trichomoniasis zinc has been suggested as a trichomonicidal component of prostatic fluid. The concentration found in normal men is lethal for most isolates of T.vaginalis. However, the existence of both zinc resistant parasites and men with below normal levels of prostatic zinc has been reported (Kreiger and Rein $1982 \mathrm{~A}$ and B). Other investigators have suggested that $T$.vaginalis is limited in its growth by the ability to acquire iron (Peterson and Alderate 1984; Graves and Gardner 1993). T.vaginalis resides within the human urogenital tract, where it is likely that key nutrients such as lipids and iron may be limiting factors. Lactoferrin is an important iron source at the site of infection. It has recently been suggested that the level of trichomonal adherence to epithelial cells was modulated by 
iron such that the presence of lactoferrin enhanced the adherence of the parasite (Lehker et al., 1990 ; 1991). Thus, iron availability from lactoferrin may be an environmental signal that triggers T.vaginalis to modulate the amount of adhesin proteins, thereby enabling the recognition and binding to the host epithelial cell. Even more importantly, given the high requirement for iron by this organism, low iron conditions at the site of infection and down regulation of adhesin synthesis may result in the parasite migrating toward more iron rich sites. The end result of such a strategy would be the persistence of this protozoan within the vagina, despite the flushing action of mucosal secretions, desquamation of the mucosal epithelium and overall nutrient Iimitations and fluxes (Lehker et al., 1991).

The vertebrate host has evolved two mechanisms of immunity. The first and phylogenetically older mechanism is the nonspecific protection provided by complement alone or in concert with phagocytes such as neutrophils and macrophages. The nonspecific factors are genetically determined and are present in every healthy individual. The second mechanism which evolved later, is the specific immune response involving antibodies and Iymphocytes. The specific immune response occurs as a reaction of the host to a particular antigenic stimulus (Roitt 1992). 


\section{NONSPECIFIC IMMUNOLOGIC DERENSE MECHANISMS:}

In trichomoniasis, nonspecific immunologic defense mechanisms include complement, neutrophils, and natural antibodies. T.vaginalis is capable of activating complement via the alternative pathway (Gillin and sher 1981). Using several different methods, the authors demonstrated the involvement of the complement system in the destruction of the parasite in the serum. The evidence of the role of complement in killing of $T$.vaginalis in serum was supported by the experiments of Shaio et al. 1993. Their results also support the killing of trichomonads through enhanced antibodydependent classical pathway of complement activation in-vitro but, very little is known about the role of complement in vaginal secretions (Demes et al., 1987). The activation of complement enables the polymorphonuclear neutrophils to surround, phagocytose and fragment T.vaginalis in to pieces (Rein et al., 1980; Shaio et al., 1991). Chemotaxis is the first step for neutrophils to phagocytose invading microorganisms. Therefore, the presence of chemoattractants will enhance phagocytosis by neutrophils. Manson and Forman (1980) reported a heat-labile chemoattractant produced by $T$.vaginalis in the presence of human serum. Shaio et al. (1992) made an attempt to identify the nature of the chemoattractant in the supernatant collected from neutrophils 
activated by $T$.vaginalis, and is most likely leukotriene $B 4$. Other investigators have described the effect of secreted neutrophil products on the migration of motile organisms. This data suggests that migration away from neutrophil products may be a means by which trichomonads evade the host immune defenses (Styrt et al., 1991).

Cytotoxicity of macrophages against $T$.vaginalis has been recognized by many investigators. Spontaneous cytotoxicity against $T$.vaginalis has been demonstrated in both unstimulated murine macrophages (Landolfo et al., 1980) and from healthy volunteer peripheral blood cells predominantly of the monocyte macrophage lineage (Mantovani et al., 1981). Studies of Rye et al. (1990) and Yoon et al. (1991) indicated that unstimulated mouse peritoneal macrophages are cytotoxic for T.vaginalis and that the addition of lymphokines increases the cytotoxicity by activating macrophages, to more efficiently kill T.vaginalis.

Natural antibody has been detected in healthy human sera. The origin of these natural antibodies in human sera is not known, but has been attributed to cross-reaction with commensal trichomonads (Ackers 1990). The role if any, of natural antibodies in human defense mechanisms is not known, but specific natural antibody is known to be able to play a stimulatory role in the activation of complement and may 
enhance complement mediated lysis, perhaps by acting as opsonins (Shaio et al., 1991).

\section{SPECIFIC IMMONOLOGIC DEFENSE MECEANISMS:}

Although individuals infected with $T$.vaginalis develop both a humoral and a cellular immune response to the organism, their role in human trichomoniasis is not clearly understood. Many tests have confirmed the existence of specific antiT.vaginalis IgM, IgG and IgA in serum, but have shed no further light on their protective function if any (Wos and Walt 1986; Cogne et al., 1985; Mathews and Healy 1983; Sibau et al., 1987; street et al., 1982; Garber et al., 1986). Honigberg (1987) showed that serum from infected persons can protect mice against the destructive effects of intraperitonealiy infected $T$. vaginalis by reducing the extent and severity of the damage caused by the parasite. However, serum from noninfected persons has no protective effect. studies of Alderete and Kasmala (1986) have also shown that monoclonal antibodies raised against $T$.vaginalis can kill the antigen-positive parasite independent of complement activation. An increase in the number of IgM, IgG and IgA secreting plasma cells was observed in the endocervix following infection with T.vaginalis, N.gonorrhoeae and Candida albicans (Chipperfield and Evans 1972), with greatest increases in IgM bearing cells in patients with 
trichomoniasis.

Many reports have been published confirming the existence of antitrichomonal antibodies in human cervicovaginal secretions by various immunological methods, and IgG and IgA antibodies were detected in the majority of reports (street et al., 1982; Lisi et al., 1986; Su-Lin 1982; Yano et al., 1982). However, the inability to find significant amounts of local antibodies in either infected men or male partners of infected women suggests that local antibodies do not play a significant role in protecting males who are exposed repeatedly to urogenital trichomonads (Ackers et al., 1978). There is also no evidence to support that local vaginal immunoglobulin plays a role in protection from $T$.vaginalis infection.

In general, little evidence is available on the potential of either the systemic or local antibody response in protection against $T$.vaginalis infection. several reports describe a cell-mediated immune response including the production and effects of Iymphokines by sensitized $T$ cells in the presence of $T$.vaginalis antigen as well as a delayed-type hypersensitivity reaction (Yano et al., 1983; Manson and Patterson 1985; Landolfo et al., 1980). However, the data is scant and further work must be done in this area before drawing any definite conclusions. Thus, the role of acquired immunity in human trichomoniasis is not clearly understood. 
Previous exposure to T.vaginalis does not appear to confer any acquisition of protection. Repeated infection with T.vaginalis may occur without significant decrease in either duration of infection or intensity of symptoms as one might expect in the presence of specific protective immune response (Ackers 1990).

\section{VACCINATION AGAINST TRICHOMONIASIS:}

Vaccination can be a very effective method of disease prevention. Different vacciation strategies are currently available for controlling infectious diseases. A killed or attenuated strain of the urganisms is used to stimulate a protective immune response. Alternatively, another substance that carries a cross-reacting antigen and which will stimulate a cross-protective immune response can serve the same function (Gordon, 1994). The latter principle was used in the development of a vaccine for trichomoniasis called solcoTrichovac (Ngumbi et al., 1984). The hypothesis proposed was that the vaccine could induce cross-reacting antibodies against abnormal lactobacilli and T.vaginalis, without adversely affecting the growth of normal lactobacilli in the vagina. However, the efficacy and mode of action of this vaccine has not yet been adequately determined (Lorenz and Ruttgers 1983; Gombosova et al., 1986) because of the lack of properly controlled clinical trials. Additional data suggested that the basic hypothesis behind Solco-Trichovac is incorrect 
because there has been no detectable cross-reaction between the lactobacillus used and T.vaginalis (Gombosova et al., 1986).

Studies of Aburel et al. (1963) used another immune-therapy type approach and met with some success. They inoculated heat killed T.vaginalis.intravaginally in infected women and showed some clinical improvement. Honigberg (1987) summarised several studies of protective immunity to $T$.vaginalis. In some studies, employment of live or killed parasites induced active immunity in mice. Utilization of hyperimmune sera from rabbits and from patients infected with the parasite also induced protective immunity in mice. Vaccination of mice with supernatant fluid of sonicated trichomonads simultaneously via the intraperitoneal and intravaginal routes met with $80 \%$ protection (Martinotti et al., 1977). Even though vaccination strategies are feasible, immunoprophylatic approaches to T.vaginalis are in their infancy. 
RATIONALE:

Trichomonas vaginalis is a major cause of the sexually transmitted trichomoniasis throughout the world. The disease is associated with a broad range of clinical symptoms ranging from a relatively asymptomatic carrier state to a well defined symptomatic condition. An epidemiologic association of HIV infection, as well as increased prenatal morbidity are some factors that illustrate the possible importance of this STD as a co-factor in other disease. Little is known about the pathogenesis and immunogenicity of T.vaginalis. As a preliminary step, an in-vivo model of immune response to T.vaginalis could provide insights into the immunogenicity of this disease.

Because of the potential side effects of metronidazole and limited potential of the current drug therapy of choice, novel strategies are needed for the control of T.vaginalis infection. Vaccination may provide an effective alternative method of prevention of this infection. It is therefore important to study the potential role of immunization of T.vaginalis in our established (McGrory and Garber 1992) mouse model of infection.

As the efficacy of the current lactobacillus vaccine, solco- 
Trichovac, is no longer accepted scientifically, vaccine development for trichomoniasis must take a different direction, perhaps by using T.vaginalis itself. Successful immunizations with the addition of an adjuvant typically result in potent immune responses, which are maintained for longer period of time. Such an immunization with T.vaginalis may open a way to control. trichomoniasis. A great deal of work must be performed before a vaccine for vaginal trichomoniasis could be available for human use. Therefore, issues of inoculum size, boosting effects, serum and vaginal antibody are all important in determining the feasibility of an immunization strategy. 


\section{HYPOTHESIS}

Prior exposure of the immune system to T.vaginalis, coupled with an adjuvant, enhances its ability to respond again to this antigen. Thus responses to second and subsequent exposure to $T$.vaginalis should be enhanced and qualitatively different from the primary, natural responses. This immune response to T.vaginalis would protect the host against subsequent infection with T.vaginalis. 


\section{OBJECTIVES}

1. To study the role of immunization with Trichomonas vaginalis in a mouse model of vaginal infection.

2. To determine if the serum and vaginal washes contain anti-Trichomonas vaginalis antibodies, after immunization.

3. To determine the optimum inoculation size of Trichomonas vaginalis required for effective immunization.

4. To study the role of multiple immunization (boosting) on protection. 


\section{MATERIAL AND METHODS}

\section{STRAINS :}

A well characterized isolate \#263 (Garber et al., 1989) recovered from a woman with symptomatic vaginitis was used for these experiments. The organism was grown as previously described (Garber et al., 1987) in $10 \mathrm{~mL}$ of Diamond's TYI-S-33 medium (TYI), pH 6.2 (Diamond et al., 1978) supplemented with $10 \%$ heat-inactivated fetal bovine serum (FBS) (Gibco Laboratories, Life Technologies Inc. Grand Island, N.Y.), 100 $\mathrm{U} / \mathrm{mL}$ penicillin, $100 \mathrm{ug} / \mathrm{mL}$ streptomycin (penicillinstreptomycin solution Gibco Laboratories) and $2.5 \mathrm{ug} / \mathrm{mL}$ amphotericin B (Gibco Laboratories) and incubated in $5 \% \mathrm{CO}_{2}$ at $37^{\circ} \mathrm{C}$. Cultures were passaged every 2-3 days. Axenic cultures were stored at $-70^{\circ} \mathrm{C}$ after being mixed with an additional $10 \%$ heat-inactivated FBS and $10 \%$ dimethyl sulfoxide.

L.acidophilus (La) (ATCC 4356) was purchased from the American Type Culture Collection, Rockville, Md. and cultured in Bacto Lactobacilli MRS broth (Difco Laboratories, Detroit, Michigan) or on MRS plates (Difco Laboratories) and incubated in $5 \% \mathrm{CO}_{2}$ at $37^{\circ} \mathrm{C}$. Cultures were passaged every 2-3 days. 
Axenic cultures in MRS broth were stored in $10 \%$ glycerol at $70^{\circ} \mathrm{C}$ until required.

\section{INTRAVAGINAI INOCULATION OF MICE:}

\section{L.acidophilus:}

Two days prior to inoculation with lactobacillus (day -9), all mice received a subcutaneous injection of $500 u$ of Delestrogen (Estradiol Valerate $10 \mathrm{mg} / \mathrm{mL}$; Squibb Canada, Montreal, Quebec) (Cooks et al., 1984; McGrory and Garber 1992). Immediately prior to inoculation with lactobacilli, the estrus cycle of each mouse was defined as previously described (Fox and Laird 1970). Vaginal smears were stained with methylene blue and cells were examined based on a detection of changes in vaginal epithelium during the cycle.

Prior to inoculation, one litre quantity of MRS broth was inoculated with $0.1 \%$ of a pure culture of L.acidophilus and incubated overnight at $37^{\circ} \mathrm{C}$ in $5 \frac{\circ}{6} \mathrm{CO}_{2}$. Organisms were then harvested by centrifugation for 10 minutes at $5,000 \mathrm{Xg}$, at $4^{\circ} \mathrm{C}$ in an Omnifuge RT (Baxter, Canlab) and washed three times in phosphate-buffered saline (PBS $\mathrm{pH} 7.2$ ). The final pellet was resuspended in MRS broth. Mice were inoculated intravaginally with an Eppendorf pipet using $20 \mathrm{uL}$ of $10^{10}$ L.acidophilus/mL on two consecutive days (days -7 and -6 ). Negative control mice were inoculated with 20 uL of MRS without L.acidophilus 
Vaginal washes were performed using 50uL of pre-warmed MRS, which was injected and aspirated into the vagina several times until turbid. Successful infection with L.acidophilus was determined by culturing vaginal washes in MRS broth supplemented with $5 \mathrm{ug} / \mathrm{mL}$ ciprofloxacin (Squibb Canada) and 180 $\mathrm{ug} / \mathrm{mL}$ cefoxitin (Mefoxin; Merck, Sharp \& Dohme) and incubated at $37^{\circ} \mathrm{C}$ for $24-48$ hr prior to $T$.vaginalis inoculation.

\section{T. vaginalis:}

Two days prior to T.vaginalis infection (day -2 ), mice were infected with a second subcutaneous dose of 500ut of Delestrogen. T.vaginalis was harvested by centrifugation for 10 minutes at $140 \mathrm{X} \mathrm{g}$ in a sorvall GLC-1 centrifuge, washed three times in PBS and the final pellet resuspended in TYI supplemented with $10 \%$ FBS and $0.32 \%$ Bacto Agar (Meysick and Garber 1992). All groups of mice were inoculated intravaginally with $20 \mathrm{uL}$ of $2.5 \times 10^{7} \mathrm{Tv} / \mathrm{mL}$ on two consecutive days (days 0 \& 1 ).

\section{ANIMALS :}

$\mathrm{BALB} / \mathrm{C}$ mice employed in this study were obtained from Charles River Co., Montreal, Canada. They were housed in plastic cages and given food and water. Mice used in this experiment were 22 to $24 \mathrm{~g}$ in weight. 


\section{IMAONIZATION EXPERIMENTS :}

\section{Inoculum preparation.}

T.vaginalis was grown to log phase in TYI and harvested by centrifugation for 10 minutes at $140 \mathrm{x} \mathrm{g}$ in a Sorvall GLC- 1 centrifuge. The pellet was washed three times in PBS by resuspension and centrifugation. The final pellet was resuspended in PBS, cells were counted and adjusted to the final concentration, 100ul of the cell preparation suspended in an equal volume of Freund's Complete Adjuvant (FCA) (total volume 200uL) were used for immunization. The same amount of the cell preparation suspended in an equal volume of Freund's Incomplete Adjuvant (FIA) was used for boosting.

As a vaccine control, one litre quantity of MRS broth was inoculated with $0.1 \%$ of a pure culture of L.acidophilus and incubated overnight at $37^{\circ} \mathrm{C}$ in $5 \% \mathrm{CO}_{2}$. Organisms were then harvested by centrifugation for 10 minutes at $5,000 \times \mathrm{g}$, at $4^{\circ} \mathrm{C}$ in an Omnifuge RT (Baxter, Canlab), washed three times in PBS $\mathrm{pH} 7.2$ and adjusted to a final concentration of $10^{7}$ L.acidophilus/mL. 100ut of the cell preparation suspended in an equal volume of FCA and FIA was used for immunization and boosting.

\section{SUBCUTANEOUS TREONIZATIONS:}

Seventy eight (26/ group) mice were subcutaneously immunized in each side of abdominal area with either $4.5 \times 10^{5}, 9 \times 10^{6}$ 
or $10 \times 10^{7} \mathrm{TV} / \mathrm{mL}$ suspended in FCA (at day -56) and 4 weeks later (day -28) boosted with the same dosage in FIA. An inoculation protocol was designed (Table 1) to determine the optimum inoculation size of $T$.vaginalis required for effective immunization. In order to confirm the optimized inoculum regimen, 12 mice were immunized and boosted with $9 \times 10^{6} \mathrm{TV} / \mathrm{mL}$ suspended in FCA and FIA, respectively (Table 2). Another set of 32 mice (16/group) were immunized only at day -28 with either TV/FCA or TV/FIA (Table 3). Another group of mice was immunized and boosted with L.acidophilus suspended in FCA and FIA, respectively (Table 2). Control mice included sham vaccinated mice, immunized with PBS ( $\mathrm{pH} 7.2$ ) in FCA and FIA or mice immunized with $9 \times 10^{6} \mathrm{Tv} / \mathrm{mL}$ in the absence of adjuvant. A third group included unimmunized controls and a final group of negative controls. 48 days after primary immunization, mice were inoculated intravaginally with L.acidophilus and 1 week later infected with T.vaginalis. At weekly intervals for 4 weeks, mice were tail bled and vaginal washes were performed. 


\section{TABLE 1}

Optimum inoculation size of $T$.vaginalis for immunization. study protocol outlining the time course for subcutaneous immunization and intravaginal challenge with $T$.vaginalis.

Sc $T V=$ Subcutaneous immunization of $T$.vaginalis

FCA = Freund's complete adjuvant.

FIA = Freund's incomplete adjuvant.

$\mathrm{La}=10^{10} \mathrm{~L}$. acidophilus inoculated intravaginally on two consecutive days (total inoculated volume $20 \mathrm{uL}$ each day)

Tv = $5 \times 10^{5} \mathrm{~T}$.vaginalis inoculated intravaginally on two consecutive days (total inoculated volume $20 \mathrm{ul}$ each day) 
Mouse strain: Balb/c.

T.vaginalis isolate \#: 263

Number of Mice: 120

Experimental Protocol:

\section{A) Immunization Schedule:}

\begin{tabular}{|c|c|c|c|}
\hline $\begin{array}{l}\text { Group } 1 \\
\left(4.5 \times 10^{5} \mathrm{TV}\right)\end{array}$ & $\begin{array}{l}\text { Group } 2 \\
\left(9 \times 10^{6} \mathrm{TV}\right)\end{array}$ & $\begin{array}{l}\text { Group } \\
\left(10 \times 10^{7} \mathrm{TV}\right)\end{array}$ & $\begin{array}{l}\text { Group } 4 \\
\text { PBS }\end{array}$ \\
\hline $\begin{array}{l}\text { DAY - } 56 \\
0.1 C C \text { TV + } \\
0.1 C C \text { FCA }\end{array}$ & $\begin{array}{l}\text { DAY - } 56 \\
0.1 C C \text { TV + } \\
0.1 C C \text { FCA }\end{array}$ & $\begin{array}{ll}\text { DAY }-56 \\
0.1 C C \text { TV } \\
0.1 C C \text { FCA }\end{array}$ & $\begin{array}{ll}\text { DAY }- & 56 \\
0.1 C C & \text { PBS } \\
0.1 C C \text { FCA }\end{array}$ \\
\hline $\begin{array}{l}\text { DAY - } 28 \\
0.1 C C \text { TV + } \\
0.1 C C \text { EIA }\end{array}$ & $\begin{array}{l}\text { DAY - } 28 \\
0.1 C C \text { TV + } \\
0.1 C C \text { FIA }\end{array}$ & $\begin{array}{ll}\text { DAY } & 28 \\
0.1 C C & T V \\
0.1 C C & \text { FIA }\end{array}$ & $\begin{array}{l}\text { DAY }-28 \\
0.1 C C \text { PBS } \\
0.1 C C \text { FIA }\end{array}$ \\
\hline
\end{tabular}

B) Infection Schedule:

DAY - 9: All mice treated subcutaneously with $0.05 c c$ Delestrogen.

DAY $-7 /-6$ : All mice inoculated with $1 \times 10^{10} \mathrm{La}$

DAY -2: All mice treated subcutaneously with $0.05 \mathrm{cc}$ Delestrogen.

DAY 0/1: All mice challenged with $2.5 \times 10^{7} \mathrm{TV} / \mathrm{ml}$

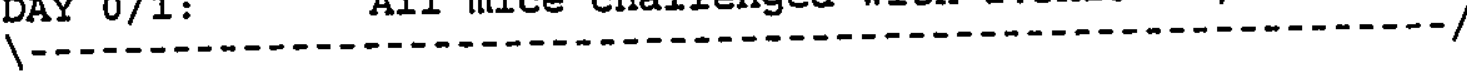

At weekly intervals for 4 weeks (days $7,14,21,28$ ) Tail bleeds and vaginal washes obtained from all mice.

c) Naive Controls:

18 Mice Designated as Naive Controls: No Sc Tv

4 Mice Designated Negative Controls: $\quad \begin{aligned} & \text { No Sc TV } \\ & \text { No La, No TV }\end{aligned}$ 


\section{TABLE 2}

Immunization regimen and role of adjuvant. study protocol outlining the time course for subcutaneous immunization and intravaginal challenge with $T$.vaginalis.

Sc $\mathrm{TV}=$ subcutaneous immunization of $T$.vaginalis

FCA = Freund's complete adjuvant.

FIA = Freund's incomplete adjuvant.

$\mathrm{La}=10^{10} \mathrm{~L}$.acidophilus inoculated intravaginally on two consecutive days (total inoculated volume $20 \mathrm{uL}$ each day)

Tv = $5 \times 10^{5} \mathrm{~T}$.vaginalis inoculated intravaginally on two consecutive days (total inoculated volume $20 u L$ each day) 
IMAONIZATION REGIMAN \& ROLE OF ADJUVANT:

Mouse strain: Balb/c.

T. vaginalis isolate \#: 263

Number of Mice: 44

\section{Experimental protocol:}

\section{A) Immunization Schedule:}

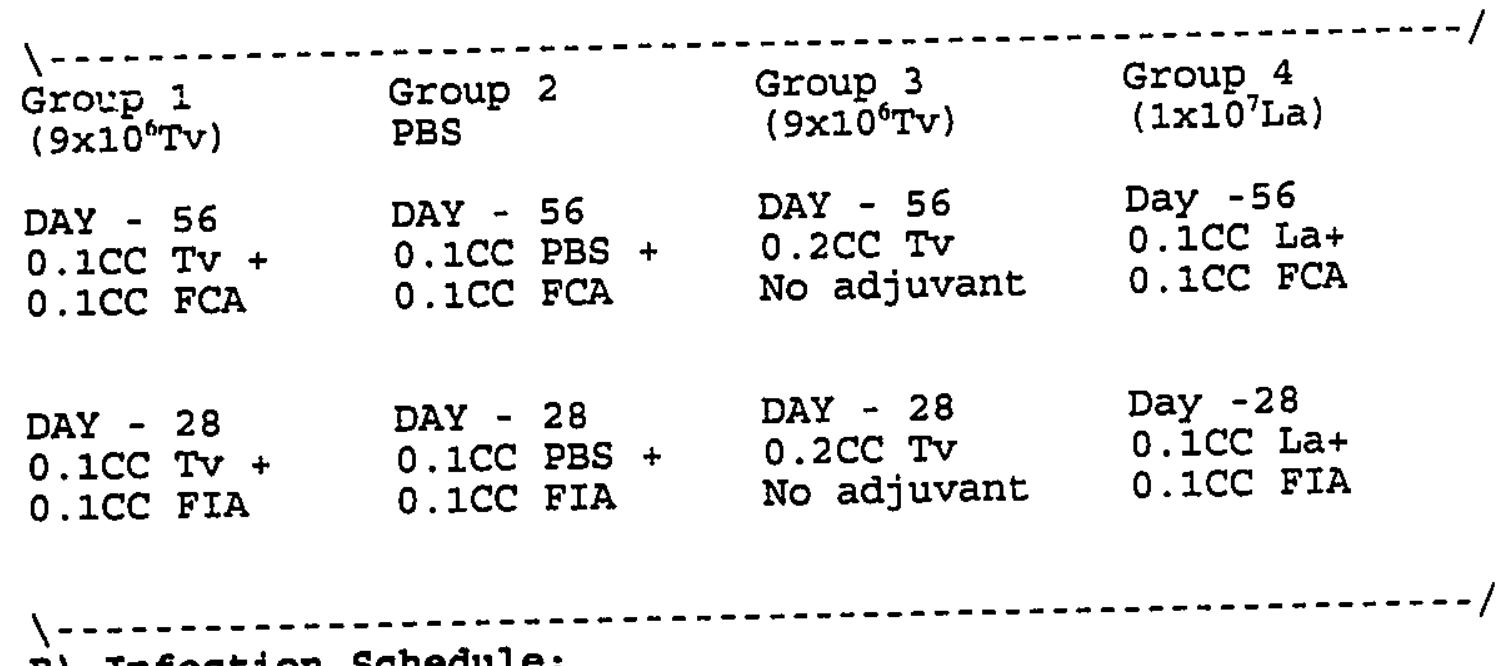

\section{B) Infection Schedule:}

DAY - 9: All mice treated subcutaneously with $0.05 \mathrm{cc}$ Delestrogen.

$\begin{array}{ll}\text { DAY }-7 /-6: & \text { All mice inoculated with } 1 \times 10^{10} \mathrm{La} \\ \text { DAY -2: } & \begin{array}{l}\text { All mice treated subcutaneously with } 0.05 \mathrm{cc} \\ \text { Delestrogen. }\end{array}\end{array}$

DAY 0/1: All mice challenged with $2.5 \times 10^{7} \mathrm{Tv} / \mathrm{ml}$

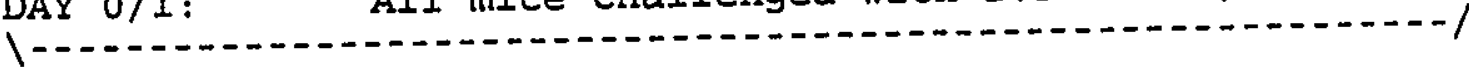

At weekly intervals for 4 weeks (days $7,14,21,28$ ) Tail bleeds and vaginal washes obtained from all mice.

\section{c) Naive Controls:}

8 Mice Designated as Naive Controls: No Sc TV

4 Mice Designated Negative Controls: No Sc TV

No La, No TV 
TABLE 3

Role of multiple immunization on protection. study protocol outlining the time course for subcutaneous immunization and intravaginal challenge with $T$.vaginalis.

Sc $\mathrm{TV}=$ subcutaneous immunization of $T$.vaginalis

FCA = Freund's complete adjuvant.

FIA = Freund's incomplete adjuvant.

La $=10^{10} \mathrm{~L}$.acidophilus inoculated intravaginally on two consecutive days (total inoculated volume 20 ul each day)

$\mathrm{Tv}=5 \times 10^{5} \mathrm{~T}$. vaginalis inoculated intravaginally on two consecutive days (total inoculated volume $20 \mathrm{uL}$ each day) 


\section{ROLE OF MOLTIPLE IMOSONIZATION:}

Mouse strain: Balb/c.

T.vaginalis isolate \#: 263

Number of Mice: 80

Experimental Protocol:

A) Immunization Schedule:

\begin{tabular}{|c|c|c|c|}
\hline Group 1 & $\begin{array}{l}\text { Group } 2 \\
\left(9 \times 10^{6} \mathrm{TV}\right)\end{array}$ & $\begin{array}{l}\text { Group } 3 \\
\left(9 \times 10^{6} \mathrm{TV}\right)\end{array}$ & $\begin{array}{l}\text { Group } 4 \\
\text { PBS }\end{array}$ \\
\hline $\begin{array}{ll}D A Y-56 \\
0.1 C C & \text { TV } \\
0.1 C C & \text { FCA }\end{array}$ & - & - & $\begin{array}{ll}\text { DAY } & 56 \\
0.1 C C & \text { PBS } \\
0.1 C C & \text { FCA }\end{array}$ \\
\hline $\begin{array}{l}\text { DAY - } 28 \\
0.1 C C \text { TV + } \\
0.1 C C \text { FIA }\end{array}$ & $\begin{array}{l}\text { DAY }-28 \\
0.1 C C \text { TV } \\
0.1 C C \text { FCA }\end{array}$ & $\begin{array}{l}\text { DAY }-28 \\
0.1 C C \text { TV } \\
0.1 C C \text { FIA }\end{array}$ & $\begin{array}{l}\text { DAY - } 28 \\
0.1 C C \text { PBS + } \\
0.1 C C \text { FIA }\end{array}$ \\
\hline
\end{tabular}

B) Infection Schedule:

DAY - 9: All mice treated subcutaneously with $0.05 \mathrm{cc}$ Delestrogen.

DAY -7i-6: All mice inoculated with $1 \times 10^{10}$ La

DAY -2: All mice treated subcutaneously with $0.05 \mathrm{cc}$ Delestrogen.

DAY 0/1: All mice challenged with $2.5 \times 10^{7} \mathrm{Tv} / \mathrm{ml}$

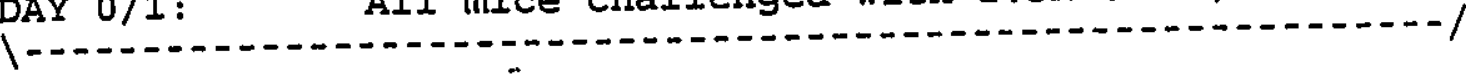

At weekly intervals for 4 weeks (days $7,14,21,28$ ) Tail bleeds and vaginal washes obtained from all mice.

c) Naive Controls:

12 Mice Designated as Naive Controls: No Sc TV

4 Mice Designated Negative Controls: No Sc TV

No Ia, No TV 


\section{RE-INEECTION EXPERIMINT:}

\section{IN METRONIDAZOLE TREATED I.VAGINALIS INEECTED MICE:}

To jompare the response of subcutaneous immunization to the effect of a prior vaginal infection in preventing a subsequent vaginal infection, 18 mice were given orally $10 \mathrm{mg} / \mathrm{mL}$ metronidazole (250mg tablet) 14 days after intravaginal inoculation with $T$.vaginalis. Metronidazole tablets were dissolved in dd $\mathrm{H}_{2} \mathrm{O}$ and $100 \mathrm{uL}$ administrated with an Eppendorf pipet. Control mice included, 9 PBS treated mice, 9 untreated mice and 4 negative controls. 3 weeks later, mice were again subjected to vaginal infection with T.vaginalis (Table 4). At weekly intervals, vaginal washes were performed for the recovery of $T$.vaginalis and serum was collected by tail. bleeds. 


\section{TABLE 4}

Re-infection experiment. Experimental protocol outlining the time course for metronidazole treatment and intravaginal challenge with $T$.vaginalis.

La $=10^{10}$ L.acidophilus inoculated intravaginally on two consecutive days (total inoculated volume $20 u L$ each day)

$\mathrm{Tv}=5 \times 10^{5} \mathrm{~T}$.vaginalis inoculated intravaginally on two consecutive days (total inoculated volume $20 u[$ each day) 


\section{RE-INEECTION EXPERIMINNT:}

Mouse strain: Balb/c.

T. vaginalis isolate \#: 263

Number of Mice:40

\section{Experimental Protocol:}

DAY -35: All Mice La intravag $x 2$ days

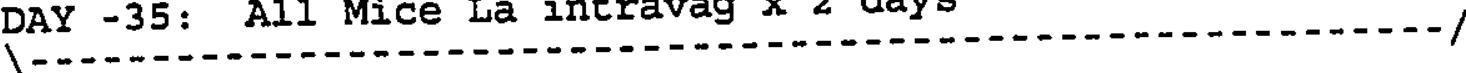

DAY- 28: All Mice TV intravag $x 2$ days

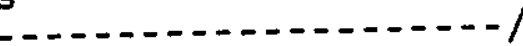

DAY - 14: Metronidazole treatment (10 mg/ml)

DAY - 7: All Mice La intravag $X 2$ days

DAY 0: Groups 1-4 TV intravag $X 2$ days

(1)

Ar weekly intervals for 4 weeks (days $7,14,21,28$ ) Tail bleeds and vaginal washes obtained from all mice.

\section{Controls:}

9 Mice designated as Naive controls.

No Metro

4 Mice designated as Negative controls.

No Metro

No La, No TV 


\section{MOUSE VAGINAT WASHES AND TAIL BLEEDS:}

Duration of infection with T.vaginalis was determined by culturing vaginal washes in TYI medium supplemented with $10 \%$ FBS and antibiotics. Infection was considered to be present as long as live trichomonads were not visible on 2 consecutive examinations. Vaginal washes were performed with 50ul prewarmed TYI supplemented with $10 \%$ FBS. The tip was inserted into the mouse vagina and the contents dispelled and aspirated until turbid. Wash material was collected in pre-warmed TYI supplemented with $10 \%$ FBS, $300 \mathrm{ug} / \mathrm{mL}$ penicillin, $300 \mathrm{ug} / \mathrm{mL}$ streptomycin, $2.5 \mathrm{ug} / \mathrm{mL}$ amphotericin $\mathrm{B}$, and $10 \mathrm{ug} / \mathrm{mL}$ gentamicin, incubated in glass, screw-capped tubes, in $5 \% \mathrm{CO}_{2}$ at $37^{\circ} \mathrm{C}$ at a $45^{\circ}$ angle and examined daily for the presence of motile $T$. vaginalis using an inverted microscope.

A second vaginal wash was done ( 3 days after first vaginal wash) with 50ul PBS. Material was collected and centrifuged for 10 minutes at $14,000 \times \mathrm{g}$ in a Heraeus Biofuge A Microfuge. The supernatant was transferred to sterile microfuge tubes and stored at $-70^{\circ} \mathrm{C}$.

Both, TYI and saline vaginal washes were performed on a weekly basis for four weeks following the intravaginal inoculations with $T$. vaginalis. Mice were tail bled for serological observation by collecting 15-20 uL of blood from 
each mouse in non-heparinized/Blue Coded Tip Microhematocrit Capillary Tubes. Samples were centrifuged for 2 minutes in a Micro-Hematocrit centrifuge (Model MB, International Equipment Co.), and serum was collected in $1.5 \mathrm{~mL}$ microfuge tubes and stored at $-70^{\circ} \mathrm{C}$.

\section{ENZYME-IINKED IMUONOSORBENT ASSAY (ELISA) :}

\section{ANTIGEN PREPARATION :}

Axenic cultures of $T$.vaginalis stored at $-70^{\circ} \mathrm{C}$ were rapidly thawed and maintained in TYI supplemented with $10 \%$ FBS and antibiotics. Cultures were passaged every $2-3$ days with a minimum of three subcultures before use in the ELISA.

An axenic culture of $T$.vaginalis in the logarithmic growth phase was harvested by centrifugation for 10 minutes at $140 \mathrm{X}$ $g$ in a Sorvall GLC-1 centrifuge, washed three times in PBS ( $\mathrm{pH}$ 7.2). The final pellet was resuspended in $10 \mathrm{~mL}$ PBS containing 1\% sodium dodecyl sulphate (SDS). The suspension was sonicated three times-for 30 seconds with 10-15 seconds pauses at maximum amplitude on ice. The suspension was then centrifuged at $50,000 \times \mathrm{g}$ at $4^{\circ} \mathrm{C}$ for 60 minutes and the pellet discarded. Protein concentration was determined by the Biorad protein assay (Bio Rad, Richmond Lab), aliquoted and stored at $-70^{\circ} \mathrm{C}$.

Ninety-six well round bottom plates (Nunc Polysorb U96), were coated with loug $T$.vaginalis antigen suspended in PBS (pH 
7.2); plates were wrapped in foil and stored at $4^{\circ} \mathrm{C}$ for a maximum of one week before use in the ELISA.

\section{ELISA TECENIQUE:}

Antigen coated plates were thawed and washed three times with washing buffer (PBS, $0.1 \%$ Tween 80 ). Test sera were diluted $1: 200$ in dilution buffer (PBS, $0.1 \%$ new born calf serum, $0.1 \%$ Tween 80 ) and 100ul was applied to each well in serial 2-fold dilution from 1:200 to 1:25600. Each serum sample was assayed in duplicate on two separate plates. After 60 minutes of incubation at room temperature, plates were washed three times with washing buffer and 100 ul of $1: 1000$ diluted ( $5 \%$ new born calf serum, $0.1 \%$ Tween 80 ) goat antimouse IgG peroxidase conjugate (Tago, Burlingame, CA) was added to each well. The plates were incubated at room temperature for 60 minutes and then washed three times with washing buffer. Colour development was performed with $100 \mathrm{uL}$ of $0.36 \mathrm{mM} \mathrm{2-2'-Azino-di-[3-ethyl-benthiazoline-6-sulfonate]} \mathrm{-}$ (ABTS) (Boeringer Mannheim) and $30 \% \mathrm{H}_{2} \mathrm{O}_{2}$ (Fisher scientific ottawa, Ontario) dissolved in citrate buffer (0.1M citrate and $0.02 \mathrm{M}$ sodium phosphate, $\mathrm{pH} 4.25$ ). After incubation at room temperature for 25 minutes, the plates were read spectrophotometrically at $405 \mathrm{~nm}$ on a Biorad Microplate Reader. Positive and negative serially diluted controls wexe included with each plate. 
The ELISA described above was also used for assays of mouse vaginal washes. Vaginal wash samples were diluted 1:1 in dilution buffer PBS (0.1\% NBCS, $0.1 \%$ Tween 80$)$ and $100 u L_{1}$ volumes were then applied in serial 2-fold dilutions to $T$ vaginalis antigen coated plates. In addition to the assays with goat anti-mouse IgG, these samples were also assayed with looul of goat-anti-mouse IgA peroxidase conjugate (Tago, Burlingame, CA).

STATISTICAI ANALYSIS :

Where applicable, data were analyzed statistically with a computer program for chi-square test (Mantel-Haenszel ChiSquare Test from Epistat).

\section{ANIMAL CARE:}

All experimental procedures and protocols involving animals were reviewed by, and set with the approval of, the University of Ottawa Animal Care Committee, protocol number OGH-36. 


\section{RESULTS}

\section{OPTIMIZATION OF EIISA}

For optimization of ELISA, different concentration of antigen and conjugated IgG were used. Ninety six well plates were coated with $0.6,1.2,2.5,5,10$ and 20 ug of $T$.vaginalis antigen and different dilutions of peroxidase conjugated goat anti-mouse IgG $(1: 1000,1: 1500,1: 2000)$, were tested.

It was established theit loug was the best amount of antigen to use with a conjugate dilution of 1:1000 for anti-IgG (Figure 1). This was tested on both negative control and positive control sera.

\section{OPTIMUM INOCULATION SIZE OR T.VAGINALIS FOR IMMUNIZATION}

In order to determine the size of inoculation of $T$.vaginalis Eor immunization, Balb/c mice were subcutaneously immunized with varying doses of $\mathrm{TV}\left(4.5 \times 10^{5}, 9 \times 10^{6}, 10 \times 10^{7} \mathrm{TV} / \mathrm{mL}\right)$ suspended in Freund's complete adjuvant (FCA) 56 days prior to vaginal infection and boosted with the same doses suspended in Freund's incomplete adjuvant (FIA) 4 weeks later (day -28).

Table 5 depicts the combined results of three separate experimental runs which define the optimal $T$.vaginalis for 


\section{FIGURE 1}

Mouse and $T$.vaginalis standard curve for serum antibody, developed by using loug of T.vaginalis antigen with a conjugate dilution of 1:1000 for peroxidase conjugated goat anti-mouse IgG.

Positive control serum.

Negative control serum. 


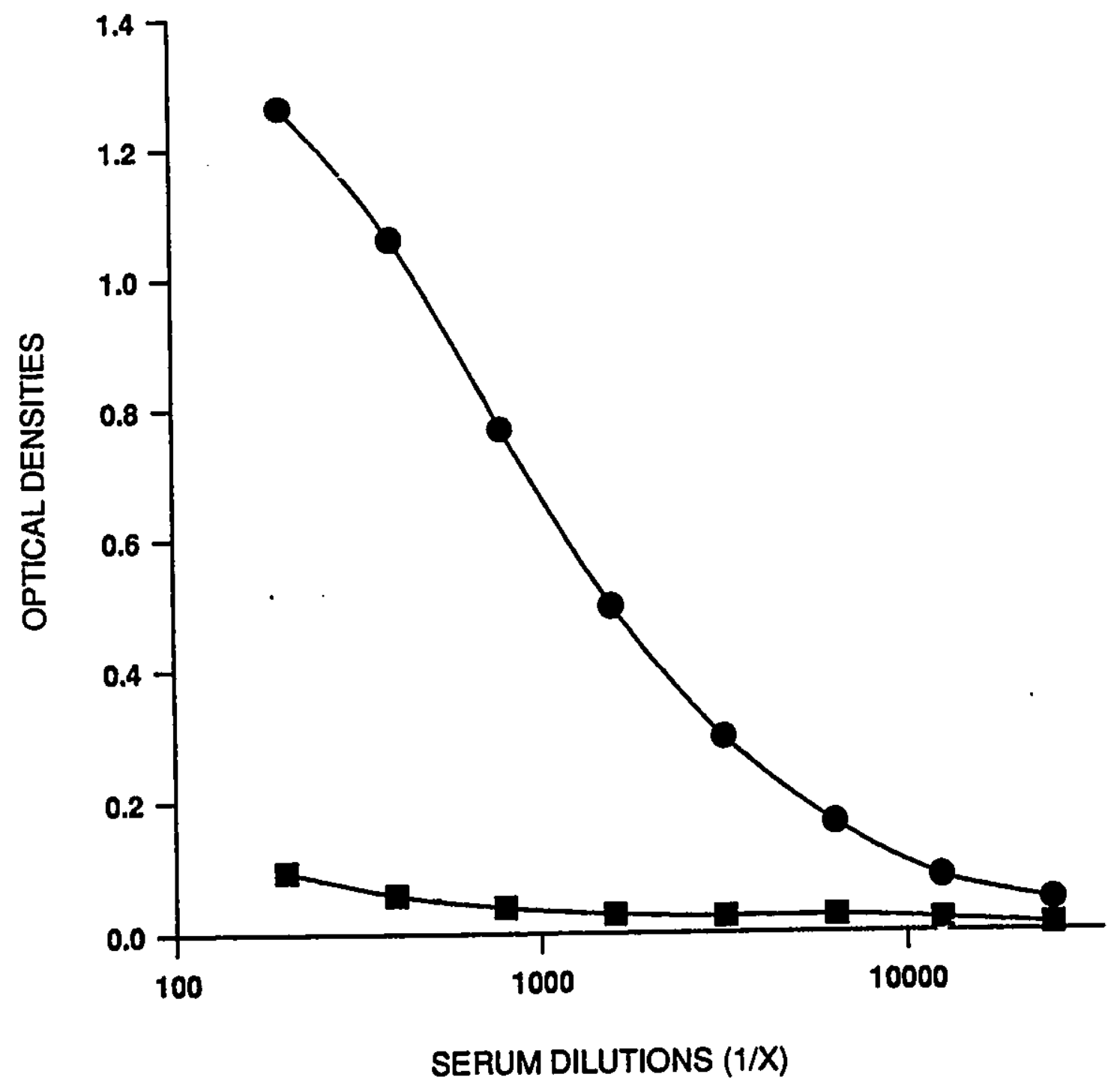


immunization dose by measuring the recovery of $T$.vaginalis from vaginal washes. The mice that were immunized and boosted with higher doses of $T$.vaginalis showed less intravaginal infection compared to mice immurized and boosted with a lower dose of $T$.vaginalis, adjuvant control or naive control mice. Seven days after intravaginal inoculation with $T$.vaginalis, only 6 of 25 mice immunized with $10 \times 10^{7} \mathrm{Tv} / \mathrm{mL}$, and 6 of 25 mice immunized with $9 \times 10^{6} \mathrm{Tv} / \mathrm{mL}$ were intravaginally infected with T.vaginalis. Twenty eight days post intravaginal inoculation, T.vaginalis could not be recovered from vaginal washes in 95.5\% of mice immunized with the $9 \times 10^{6} \mathrm{Tv} / \mathrm{mL}$ dose and $100 \%$ of mice immunized with the $10 \times 10^{7} \mathrm{Tv} / \mathrm{mL}$ dose. Twelve of 26 mice immunized and boosted with $4.5 \times 10^{5} \mathrm{Tv} / \mathrm{mL}$ were infected seven days after intravaginal inoculation with T.vaginalis. At 28 days post infection 7 mice were still infected. Sixteen of the 17 mice in the PBS immunized group and 14 of the 16 in the naive control group were intravaginally infected at day 7 . Eight of the 14 mice in the PBS immunized group and 7 of 15 mice in the naive control groups were still intravaginally infected 28 days post intravaginal inoculation. There was a statistically significant decrease in the recovery of T.vaginalis in mice immunized with $4.5 \times 10^{5} \mathrm{Tv} / \mathrm{mL}(p=<0.01)$, $9 \times 10^{6} \mathrm{TV} / \mathrm{mL}(\mathrm{p}=<0.0001)$ and $10 \times 10^{7} \mathrm{TV} / \mathrm{mL} \quad(\mathrm{p}=<0.0001)$ compared to naive controls (Figure 6). Statistically significant decrease in the recovery of $T$.vaginalis was also noticed in mice immunized with $9 \times 10^{6} \mathrm{TV} / \mathrm{mL} \quad(p=<0.01)$ and $10 \times 10^{7} \mathrm{TV} / \mathrm{mL}$ 
$(\mathrm{p}=<0.01)$ compared to mice immunized with $4.5 \times 10^{5} \mathrm{Tv} / \mathrm{mL}$. No significant difference in recovery of $T$.vaginalis in over 28 days was observed between naive controls and sham vaccinated mice $(p=0.99)$. The six negative control animals had no detectable $T$.vaginalis.

ANTIBODY RESPONSE IN SERUM AND VAGINAL WASHES

Figure 3 illustrates, the influence of immunization on serologic IgG response of mice to $T$.vaginalis detected by ELISA. The PBS immunized mice group, naive control group and negative control group showed low IgG response throughout the experiment. The groups of mice immunized with $9 \times 10^{6} \mathrm{TV} / \mathrm{mL}$ and $10 \times 10^{7} \mathrm{Tv} / \mathrm{m}$ were showing higher IgG response compared to the group immunized with $4.5 \times 10^{5} \mathrm{Tv} / \mathrm{mL}$ or control mice. Immunization with $T$.vaginalis antigen in adjuvant induced an increased serum IgG response following challenge with an intravaginal inoculation of T.vaginalis.

Figures 4 and 5 represent IgG and IgA responses in vaginal washes of immunized mice upon challenged with $T$.vaginalis. A pronounced vaginal IgG response was observed in mice immunized with $9 \times 10^{6} \mathrm{TV} / \mathrm{mL}$ and $10 \times 10^{7} \mathrm{TV} / \mathrm{mL}$, but a low IgG response in mice immunized with $4.5 \times 10^{5} \mathrm{Tv} / \mathrm{mL}$. All control groups showed low IgG reactivity to T.vaginalis antigen. Vaginal IgA response was not as pronounced as in the case of vaginal IgG. 
Mice immunized with the two higher concentrations of $T$.vaginalis antigen showed a slight elevation 14 days after infection. Similar to the control groups, immunization with low dose antigen did not induce a detectable increase in vaginal IgA response. These experiments provide some evidence that previous exposure to T.vaginalis through subcutaneous immunization results in elevated response of antibodies in vaginal washes and serum, particularly subsequent to a vaginal infection. 
TABIE 5. Recovery of Trichomonas vaginalis in Mouse Vaginal Washes (Optimum Inoculation size of Tv for Immunization)

\section{Days of Culture (positive)}

\begin{tabular}{|c|c|c|c|c|}
\hline Mouge Group & \pm 7 & \pm 14 & \pm 21 & +28 \\
\hline $\begin{array}{l}\text { Group } 1(n=26) \\
4.5 \times 10^{5} \mathrm{TV} / \mathrm{mI}\end{array}$ & $12 / 26$ & $10 / 25^{*}$ & $8 / 25 *$ & $7 / 25 *$ \\
\hline $\begin{array}{l}\text { Group } 2(n=26) \\
9 \times 10^{6} \mathrm{Tv} / \mathrm{mr}\end{array}$ & $6 / 25 *$ & $5 / 25 *$ & $3 / 24 \star$ & $1 / 24 *$ \\
\hline $\begin{array}{l}\text { Group } 3(n=26) \\
10 \times 10^{7} \mathrm{TV} / \mathrm{mI}\end{array}$ & $6 / 25^{*}$ & $4 / 23 *$ & $1 / 21 *$ & $0 / 21 *$ \\
\hline $\begin{array}{l}\text { Group } 4(n=18) \\
\text { PBS }\end{array}$ & $16 / 17^{*}$ & $13 / 16 *$ & $9 / 15^{\star}$ & $8 / 14 *$ \\
\hline $\begin{array}{l}\text { Group } 5(n=18) \\
\text { No Immunization }\end{array}$ & $14 / 16^{\star}$ & $12 / 16^{*}$ & $10 / 15^{*}$ & $7 / 15^{*}$ \\
\hline $\begin{array}{l}\text { Group } 6(n=6) \\
\text { Neg. Control. }\end{array}$ & $0 / 6$ & $0 / 6$ & $0 / 6$ & $0 / 6$ \\
\hline
\end{tabular}

$T V=T . v a g i n a l i s$

* Changes in the denominator of the different columns are accounted for by unrelated death of mice. 


\section{FIGURE 2}

Optimum inoculation size of $T$.vaginalis for immunization. Survivorship analysis estimating probability of recovery of T. vaginalis over time.

Group of mice immunized and boosted with $4.5 \times 10^{5} \mathrm{Tv} / \mathrm{mLL}$.

Group of mice immunized and boosted with $9 \times 10^{6} \mathrm{TV} / \mathrm{mL}$.

A Group of mice immunized and boosted with $1 \times 10^{8} \mathrm{Tv} / \mathrm{mL}$.

$\nabla$ Group of mice immunized and boosted with PBS.

$\checkmark$ Group of unimmunized mice (naive control). 


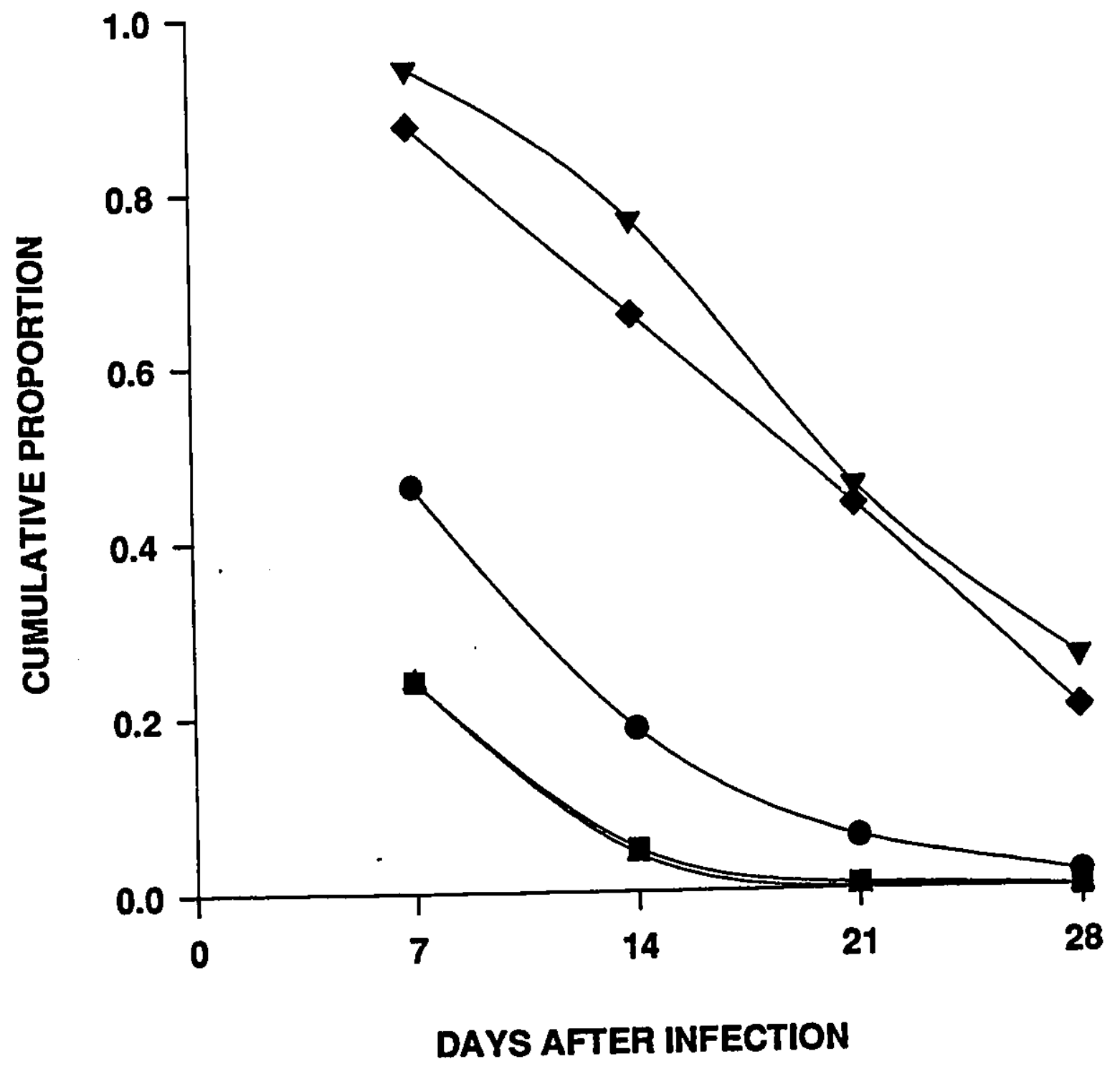




\section{FIGURE 3}

Optimum inoculation size of T.vaginalis for immunization. Kinetics of IgG serologic response to $T$.vaginalis as measured by EIISA.

Group of mice immunized and boosted with $4.5 \times 10^{5} \mathrm{TV} / \mathrm{ml}$.

a Group of mice immunized and boosted with $9 \times 10^{6} \mathrm{TV} / \mathrm{ml}$.

$\Delta$ Group of mice immunized and boosted with $10 \times 10^{7} \mathrm{TV} / \mathrm{ml}$.

$\nabla$ Group of mice immunized and boosted with PBS. 


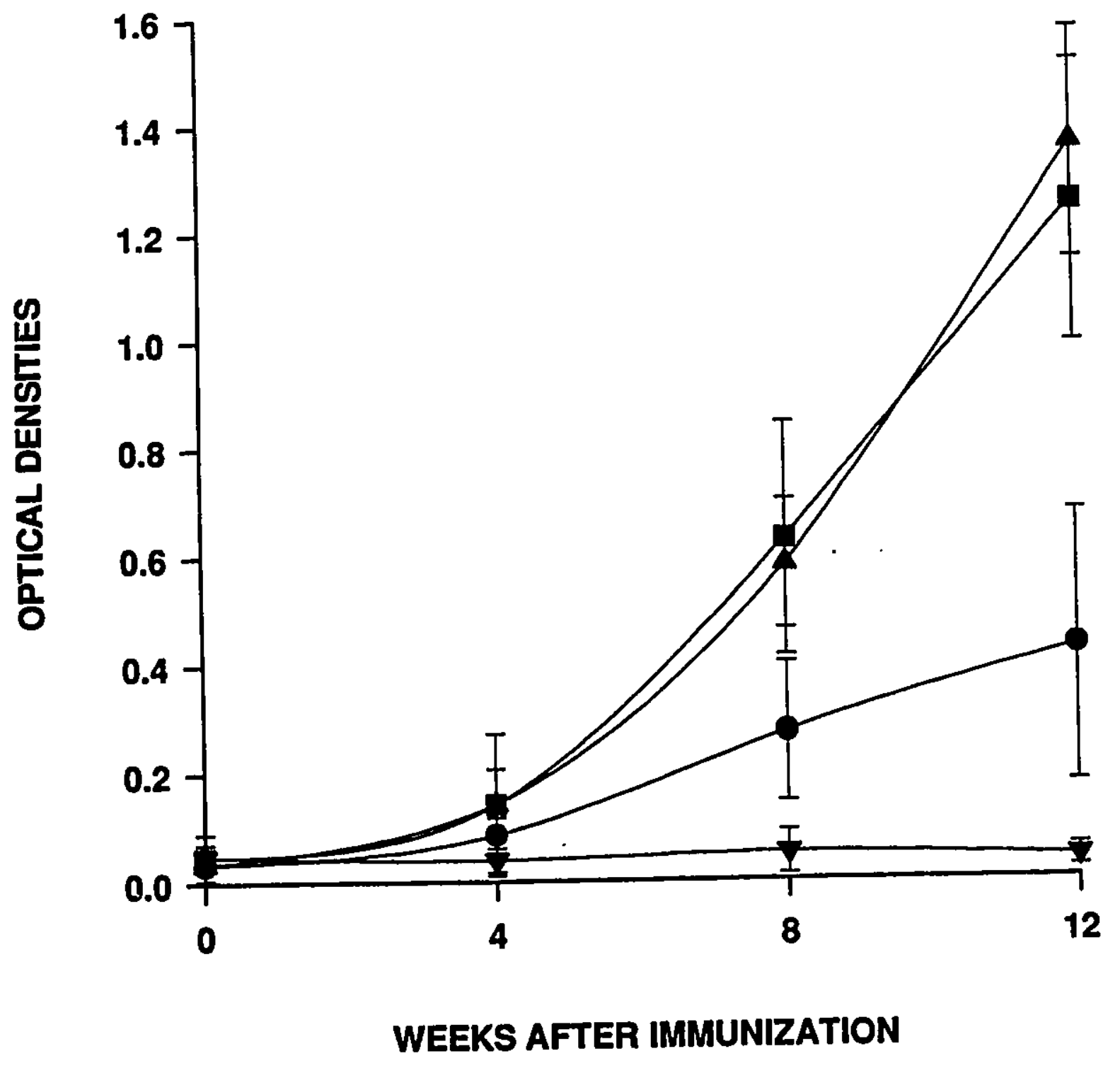




\section{FIGURE 4}

Optimum inoculation size of T.vaginalis for immunization. Kinetics of vaginal IgG response to $T$.vaginalis as measured by ELISA.

Group of mice immunized and boosted with $4.5 \times 10^{5} \mathrm{TV} / \mathrm{mL}$.

$\square$ Group of mice immunized and boosted with $9 \times 10^{6} \mathrm{Tv} / \mathrm{mL}$.

$\Delta$ Group of mice immunized and boosted with $1 \times 10^{8} \mathrm{TV} / \mathrm{mL}$.

$\nabla$ Group of mice immunized and boosted with PBS. 


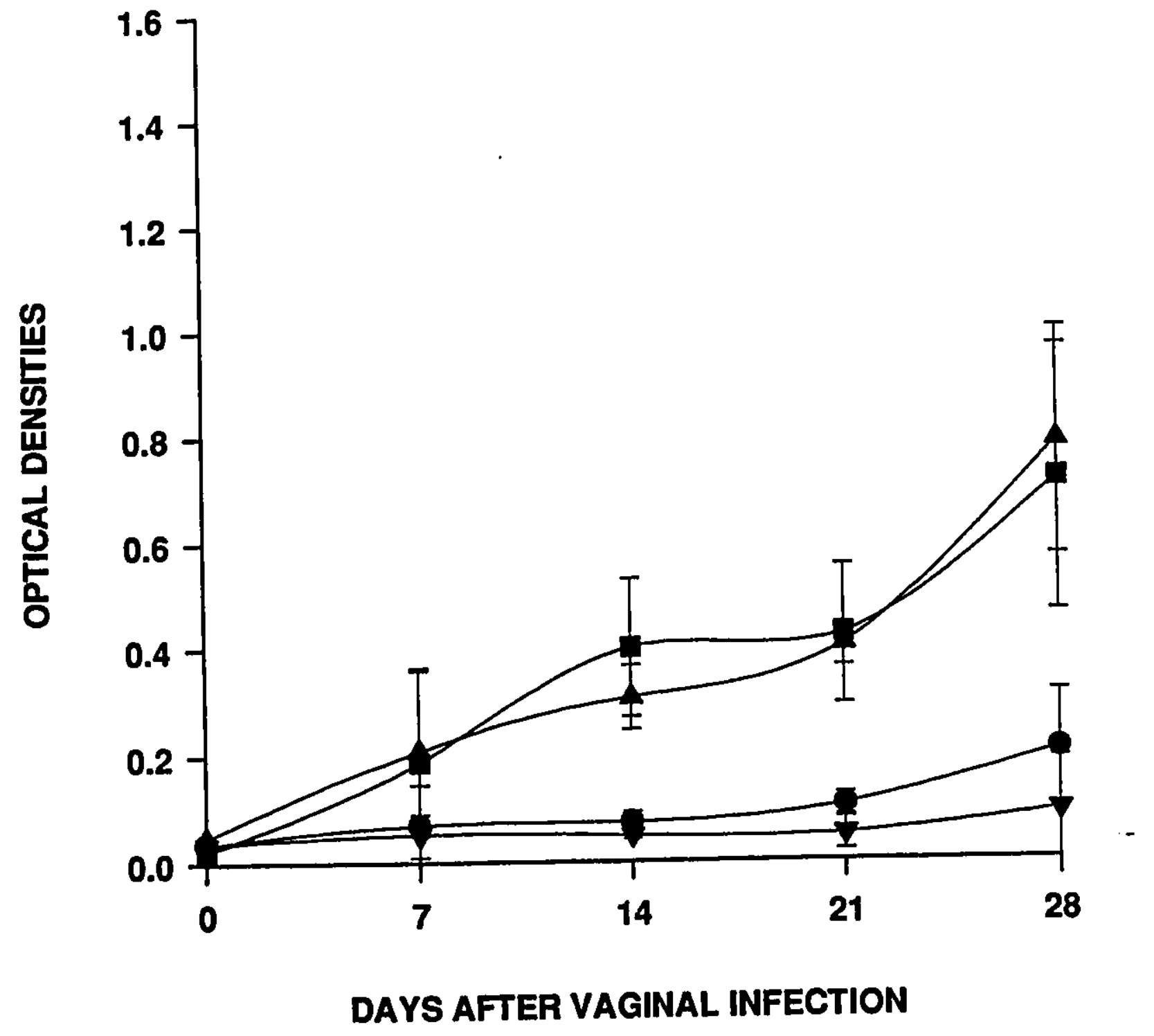




\section{EIGURE 5}

Optimum inoculation size of T.vaginalis for immunization. Kinetics of vaginal IgA response to $T$.vaginalis as measured by ELISA.

Group of mice immunized and boosted with $4.5 \times 10^{5} \mathrm{TV} / \mathrm{mL}$.

- Group of mice immunized and boosted with $9 \times 10^{6} \mathrm{TV} / \mathrm{mL}$.

$\Delta$ Group of mice immunized and boosted with $1 \times 10^{8} \mathrm{TV} / \mathrm{mL}$.

$\nabla$ Group of mice immunized and boosted with PBS. 


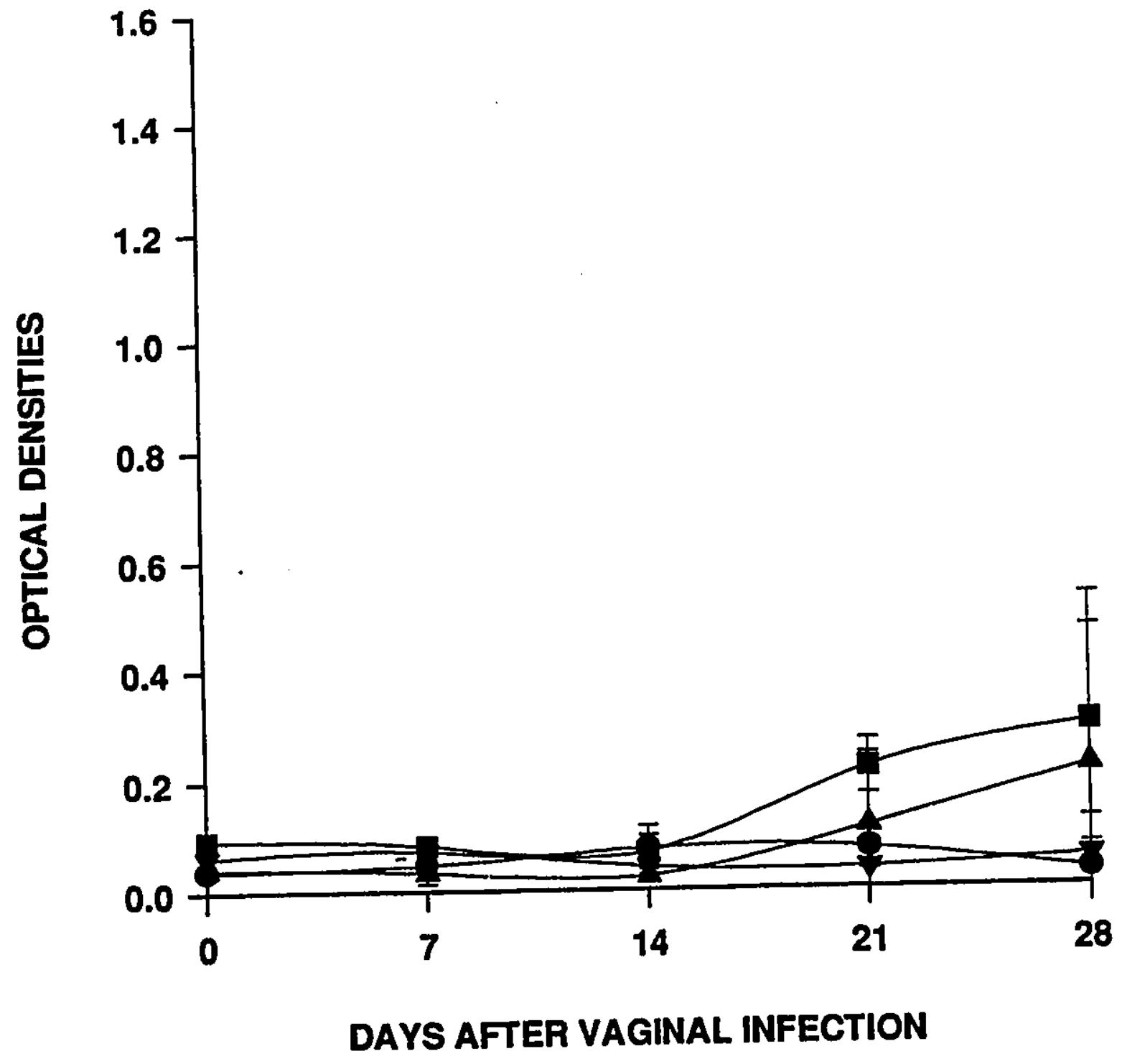


IMMONIZATION REGIMEN OF T.VAGINALIS.

We determined the optimal immunization regimen with T.vaginalis as measured by observing the influence of subcutaneous immunization with $9 \times 10^{6} \mathrm{Tv} / \mathrm{mL}$ on antibody response to intravaginal challenge, and on the ability of the trichomonads to establish infection in the vagina. The combined results of two separate trials examining the recovery of T.vaginalis from cultures of vaginal washes are presented in Table 6 . The number of mice infected with $T$.vaginalis after intravaginal inoculation is presented as the ratio of mice infected to the total number of mice inoculated. The mice immunized and boosted with T.vaginalis suspended in Freund's adjuvant were less likely to establish intravaginal infection with T.vaginalis compared to the other group of mice. Seven days after intravaginal inoculation, $T$.vaginalis was recovered in 3 of 12 mice in the test group and all 3 cleared the infection 28 days post intravaginal inoculation. Hence the mice that were immunized and boosted with trichomonad suspended in Freund's adjuvant either did not become infected with T.vaginalis upon intravaginal challenge or cleared the infection after 21 days. Basically, all mice in sham inoculated group were infected by day 7 . Even after 28 days of post intravaginal inoculation, 4 of 6 PBS immunized mice and 2 of 4 immunized with T.vaginalis but without adjuvant were infected. Similarly, 4 of 7 mice immunized with 
L.acidophilus and 5 of 7 naive control mice were still infected by 28 days of post infection. Statistically, $T$.vaginalis was not recovered from the vaginal washes of mice immunized with $T$.vaginalis suspended in Freund's adjuvant prior to vaginal infection compared to naive controls $(p=<0.0001)$. No significant difference in recovery of $T$.vaginalis over 28 days was observed between naive controls and sham vaccinated mice $(p=0.99)$, mice immunized without adjuvant $(p=0.87)$ and mice immunized with L.acidophilus $(p=0.73)$. This indicates that significant procection and/or clearence only occurs in the mice that received immunization with $T$.vaginalis in the adjuvant (Figure 6 ). The four negative control mice had no detectable $T$.vaginalis indicating that $T$.vaginalis is not found naturally in mice.

\section{ANTIBODY RESPONSE IN SERUM AND VAGINAL WASHES}

To define the serologic response to $T$.vaginalis infection and immunization, all groups of mice were tail bled 56 and 28 days prior to infection, the day of infection (day 0 ) and 28 days post infection by ELISA (Figure 7). In the test group of mice, there was a pronounced IgG response and there was further elevation of IgG response after intravaginal challenge. The IgG response in mice previously immunized with subcutaneous $T$.vaginalis increased over time. This experiment provided some evidence that previous exposure to T.vaginalis 
suspended in adjuvant results in elevation of IgG response to intravaginal inoculation with $T$.vaginalis. In the sham immunized group, the serologic IgG response was negligible, and the IgG antibody response remained low throughout the experiment, even after vaginal infection.

Figures 8 and 9 represent autibody reactivity detected by ELISA in the vaginal washes $7,14,21$ and 28 days post intravaginal infection. Only the group of mice immunized and boosted with $T$.vaginalis in adjuvant showed an increased vaginal IgG response (Figure 8 ) whereas all the control groups showed low antibody response throughout the period. Even though the vaginal IgA response of the test group was not as - elevated as serum IgG or vaginal IgG, there was a gradual rise in vaginal IgA after 14 days of infection. The vaginal IgA response (Figure 9) of all control groups were low. In our assay, mice previously exposed to T.vaginalis suspended in Freund's adjuvant showed an increased vaginal antibody response as compared to the control groups of mice. 
TABLE 6. Recovery of Trichomonas vaginalis in Mouse Vaginal Washes

(Immunization regimen \& role of adjuvant)

Days of Culture (positive)

\begin{tabular}{|c|c|c|c|c|}
\hline Mouse Group & \pm 7 & \pm 14 & \pm 21 & \pm 28 \\
\hline $\begin{array}{l}\text { Group } 1(n=12) \\
9 \times 10^{6} \mathrm{TV} / \mathrm{m}^{2}+\mathrm{EA}\end{array}$ & $3 / 12$ & $2 / 11 *$ & $1 / 11 \star$ & $0 / 11 *$ \\
\hline $\begin{array}{l}\text { Group } 2(n=6) \\
\text { PBS+FA }\end{array}$ & $6 / 6$ & $5 / 6$ & $4 / 6$ & $4 / 6$ \\
\hline $\begin{array}{l}\text { Group } 3(n=6) \\
9 \times 10^{6} \mathrm{TV} / \mathrm{mL}-\mathrm{FA}\end{array}$ & $4 / 5^{\star}$ & $4 / 5 *$ & $3 / 5 *$ & $2 / 4 * *$ \\
\hline $\begin{array}{l}\text { Group } 4(\mathrm{n}=8) \\
10^{7} \mathrm{IA}+\mathrm{EA}\end{array}$ & $6 / 8$ & $6 / 8$ & $4 / 7 \star$ & $4 / 7 *$ \\
\hline $\begin{array}{l}\text { Group } 5(n=8) \\
\text { No Immunization }\end{array}$ & $7 / 7 *$ & $6 / 7 *$ & $6 / 7 *$ & $5 / 7 *$ \\
\hline $\begin{array}{l}\text { Group } 6(n=4) \\
\text { Neg. Control. }\end{array}$ & $0 / 4$ & $0 / 4$ & $0 / 4$ & $0 / 4$ \\
\hline
\end{tabular}

TV= T.vaginalis

* Changes in the denominator of the different columns are accounted for by unrelated death of mice. 
61

\section{FIGURE 6}

Immunization regimen and role of acjuvant.

Survivorship analysis estimating probability of reccivery of $T$. vaginalis over time.

Group of mice immunized and boosted with $9 \times 10^{6} \mathrm{Tv} / \mathrm{mL}$ in Freund's adjuvant.

Group of mice immunized and boosted with PBS.

$\Delta$ Group of mice immunized and boosted with $9 \times 10^{6} \mathrm{Tv} / \mathrm{mL}$ without adjuvant.

$\nabla$ Group of mice immunized and boosted with $1 \times 10^{7} \mathrm{La} / \mathrm{mL}$ in Freund's adjuvant.

$\checkmark$ Group of unimmunized mice (naive control). 


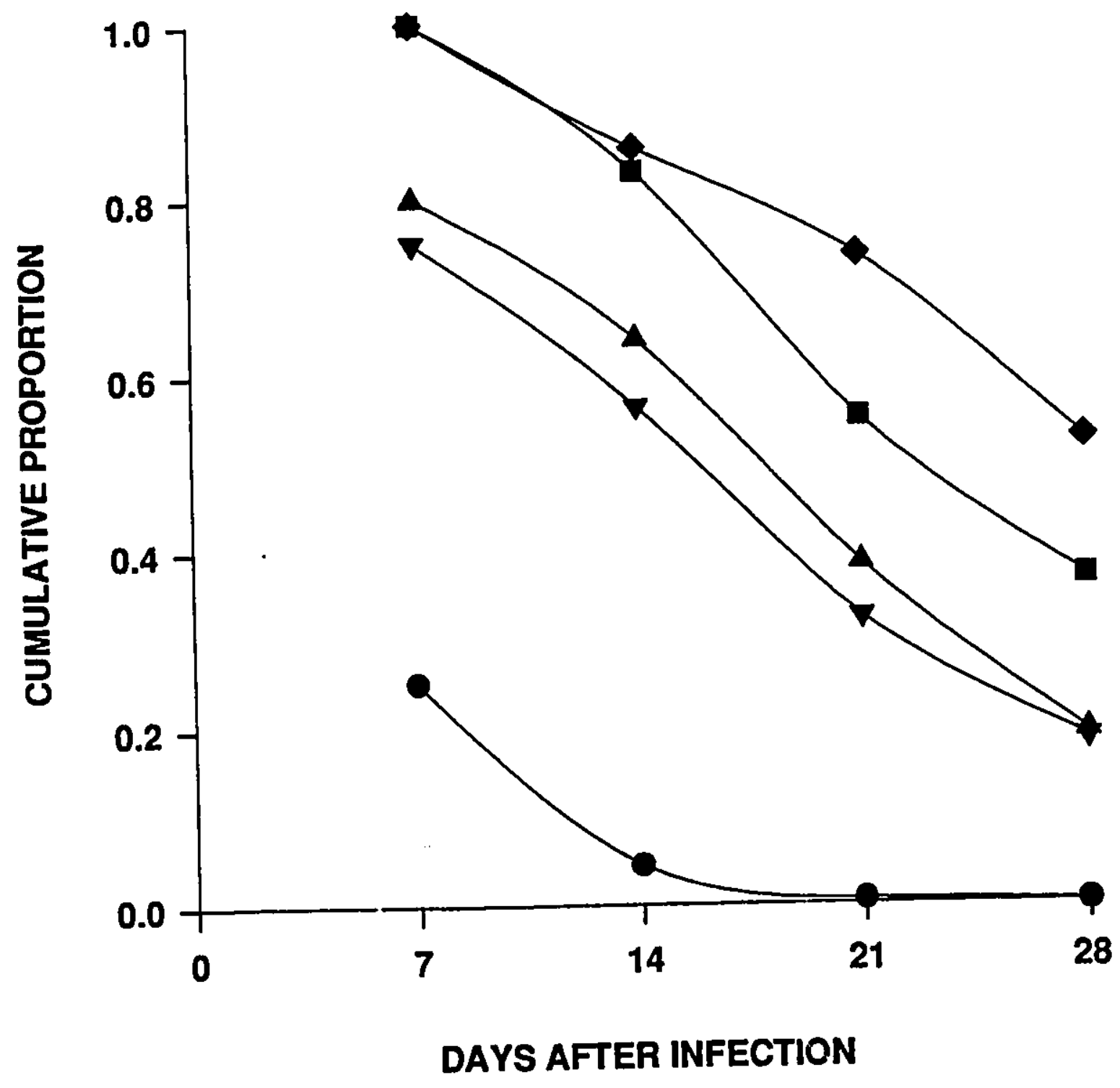




\section{EIGURE 7}

Immunization regimen and role of adjuvant.

Kinetics of IgG serologic response to $T$.vaginalis as measured by ELISA.

Group of mice immunized and boosted with $9 \times 10^{6} \mathrm{Tv} / \mathrm{mL}$ in Freund's adjuvant.

Group of mice immunized and boosted with PBS.

$\Delta$ Group of mice immunized and boosted with $9 \times 10^{6} \mathrm{TV} / \mathrm{mL}$ without adjuvant.

$\nabla$ Group of mice immunized and boosted with $1 \times 10^{7} \mathrm{La} / \mathrm{mL}$ in Freund's adjuvant. 


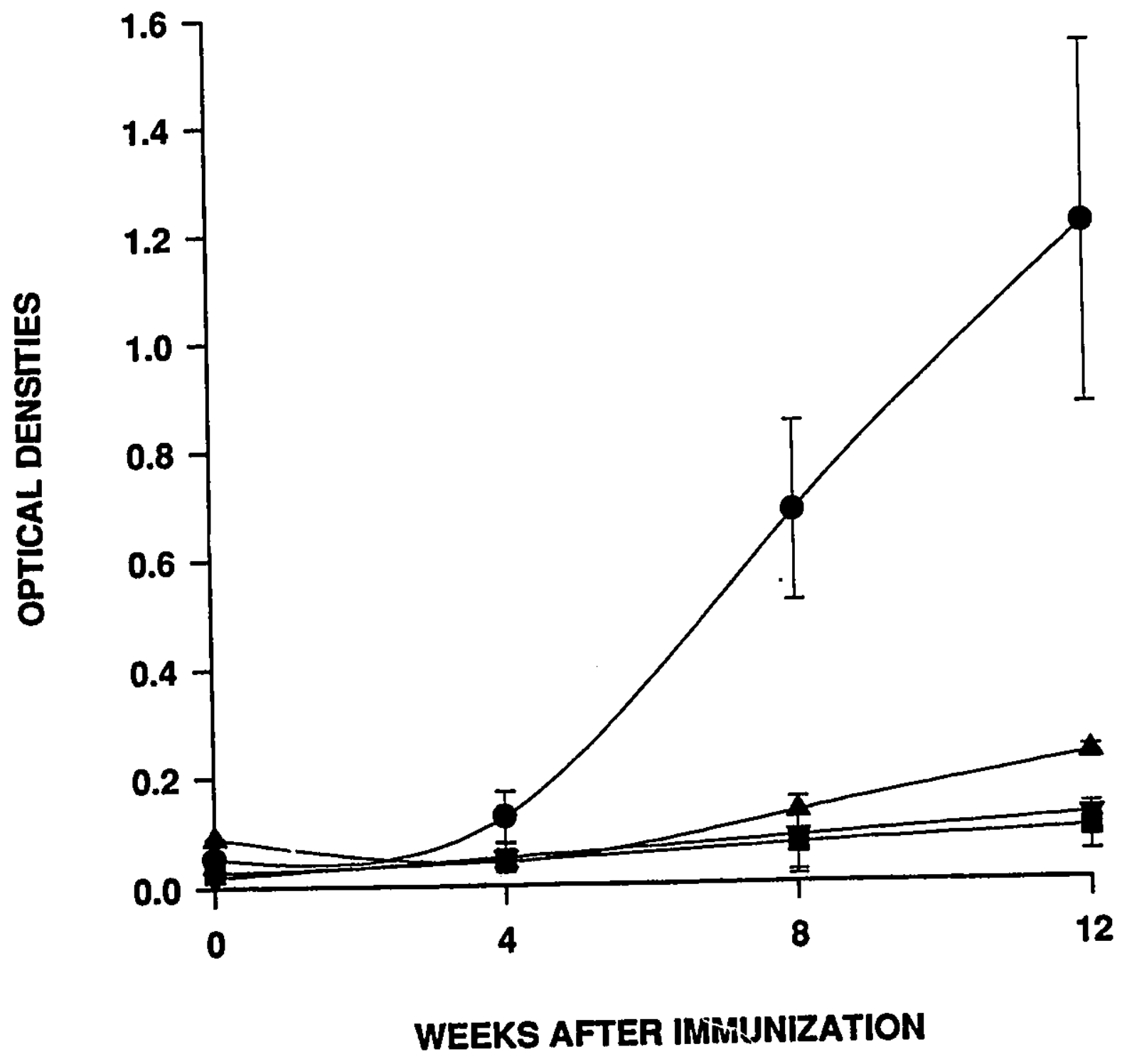




\section{PIGURE 8}

Immunization regimen and role of adjuvant.

Kinetics of vaginal IgG response to $T$.vaginalis as measured by ELISA.

- Group of mice immunized and boosted with $9 \times 10^{6} \mathrm{TV} / \mathrm{mL}$ in Freund's adjuvant.

Group of mice immunized and boosted with PBS.

$\Delta$ Group of mice immunized and boosted with $9 \times 10^{6} \mathrm{Tv} / \mathrm{mL}$ without adjuvant.

$\nabla$ Group of mice immunized and boosted with $1 \times 10^{7} \mathrm{La} / \mathrm{mL}$ in Freund's adjuvant. 


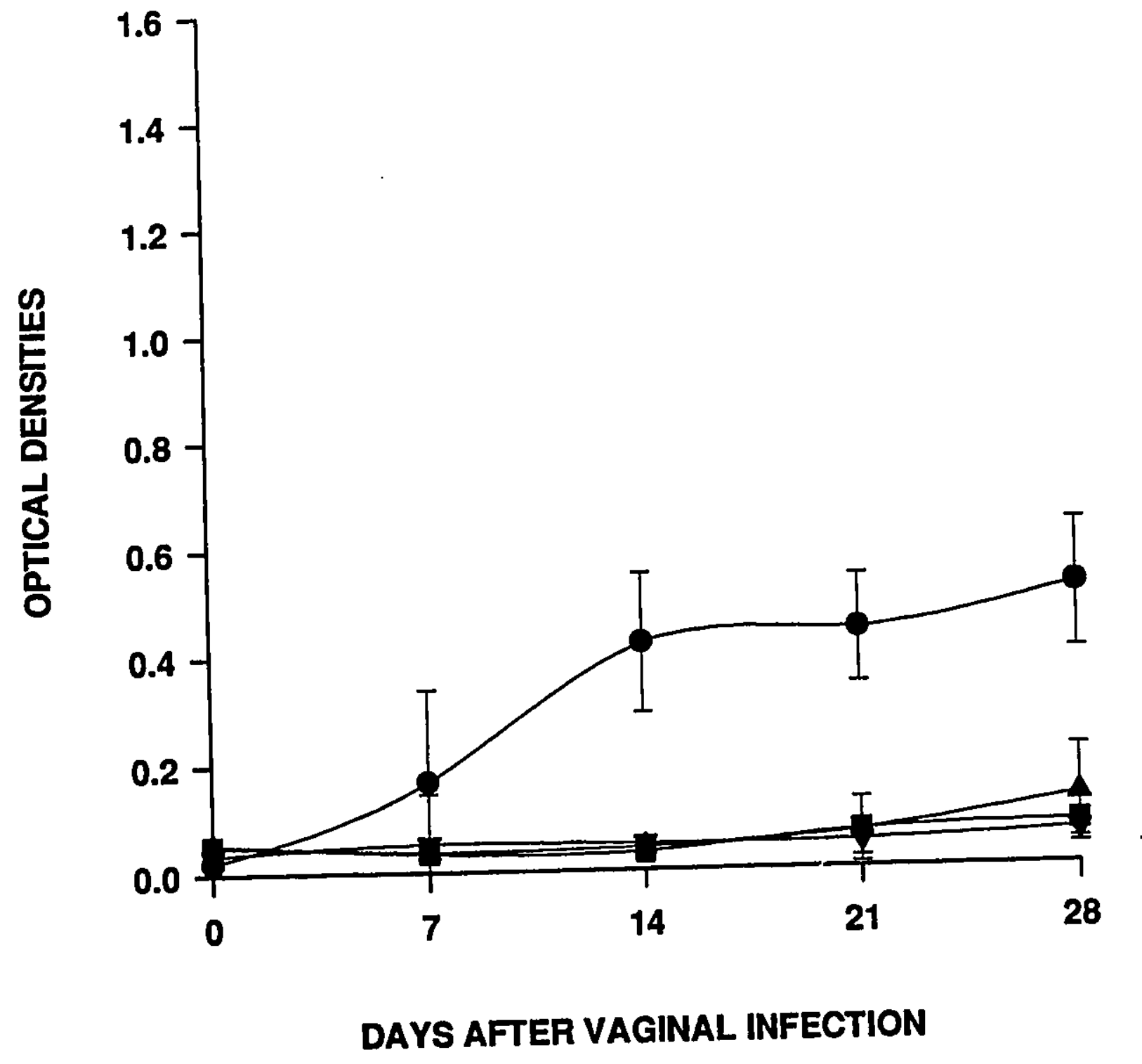




\section{FIGURE 9}

Immunization regimen and role of adjuvant. Kinetics of vaginal IgA response to $T$.vaginalis as measured by ELISA.

Group of mice immunized and boosted with $9 \times 10^{6} \mathrm{Tv} / \mathrm{mL}$ in Freund's adjuvant.

Group of mice immunized and boosted with PBS.

$\Delta$ Group of mice immunized and boosted with $9 \times 10^{6} \mathrm{TV} / \mathrm{mL}$ without adjuvant.

$\nabla$ Group of mice immunized and boosted with $1 \times 10^{7} \mathrm{La} / \mathrm{mL}$ in Freund's adjuvant. 


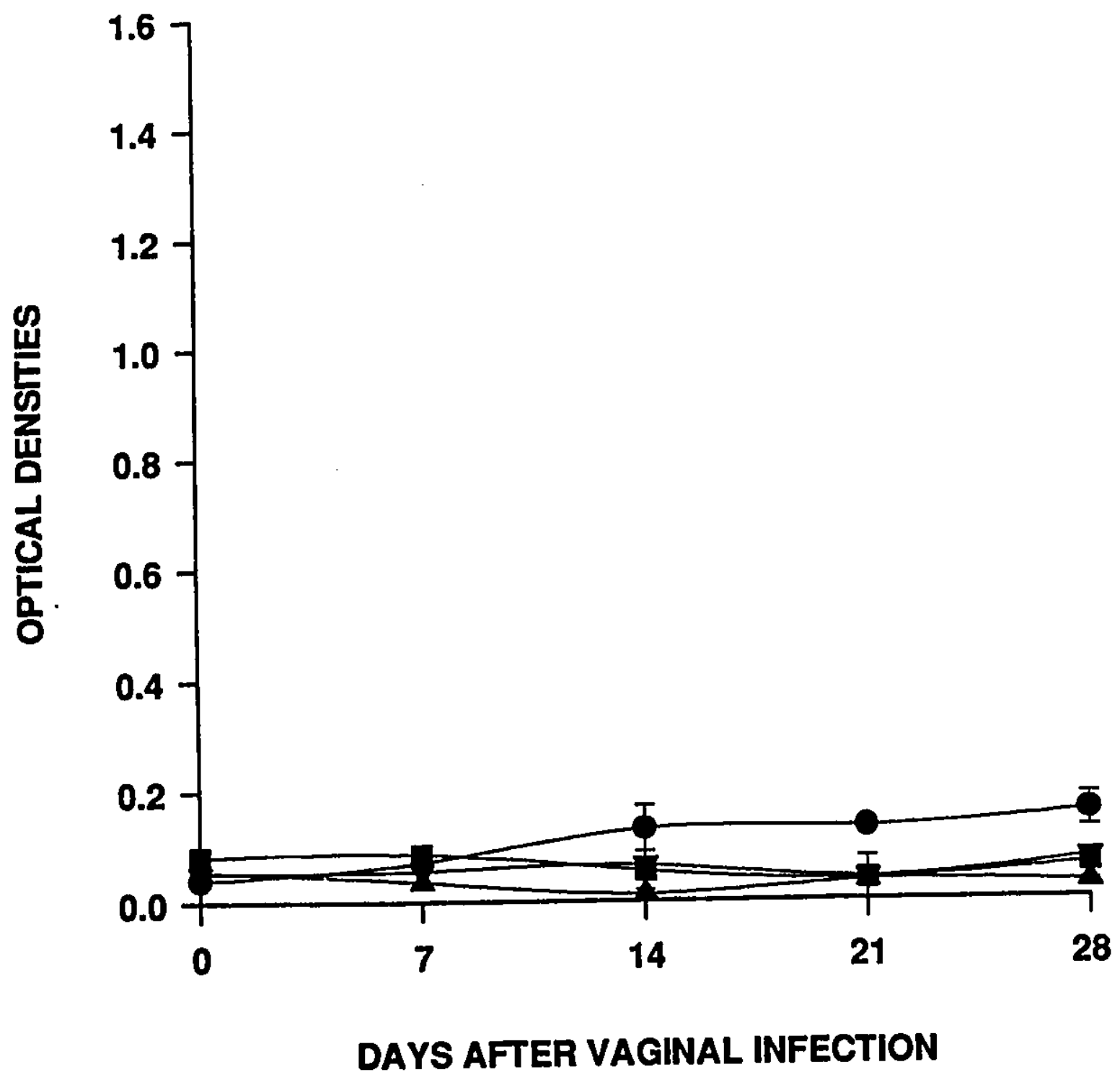




\section{IMPORTANCE OF BOOSTING:}

To examine the importance of booster inoculation on protection against intravaginal challenge with $T$.vaginalis, mice were immunized with $9 \times 10^{6} \mathrm{TV} / \mathrm{mL}$ suspended in FCA at day-56 and boosted with FIA at day -28 or immunized only at day -28 with either TV/FCA or TV/FIA. Control mice were immunized with PBS suspended in FCA at day -56 and boosted with FIA at day -28 .

The combined results of two separate runs examining the recovery of $T$.vaginalis from vaginal washes are shown in Table 7. Mice immunized and boosted with T.vaginalis antigen preparation prior to intravaginal challenge were less likely to be infected with $T$.vaginalis than mice receiving a single immunizing dose or mice not previously exposed to $T$.vaginalis. In the immunized group, 7 days after intravaginal challenge, $T$. vaginalis could be recovered from vaginal washes in 5 of the 20 mi.ce but only 1 of 20 immunized mice was still infected 28 day's after intravaginal challenge with $T$.vaginalis. The mice that received a single immunizing dose of $T$.vaginalis in FCA, 28 days prior to the intravaginal challenge, 10 of the 16 mice were infected by 7 days of post intravaginal ir.ection, 5 of the 14 mice were still infected on day 28 . These results were similar to those in mice receiving a single immunizing dose of T.vaginalis in FIA, 28 days prior to the intravaginal 
challenge, 6 of 14 mice were infected on day 28 . T.vaginalis was not recovered from the vaginal washes of mice immunized and boosted with $T$.vaginalis prior to vaginal infection compared to naive controls $(p=<0.0001)$. No significant difference in the recovery of T.vaginalis over 28 days was observed between naive controls and mice that received only one immunization in FCA $(p=0.824)$, mice that received only one immunization in FIA $(p=0.704)$ and sham immunized mice $(p=0.99)$ (Figure 10). Most of the control mice were infected throughout the period.

Figure 11 represents the reactivity of IgG detected by ELISA in serum samples $0,4,8$ and 12 weeks post immunization. The group of mice immunized and boosted prior to the intravaginal challenge elicited an elevated IgG response. An increase in antibody reactivity was observed upon booster immunization and vaginal infection when compared to the group of mice that received only a single immunizing dose prior to vaginal infection. In our assay, mice previously immunized with T.vaginalis antigen preparation showed an increase in serum T.vaginalis IgG reactivity compared to negative control mice which had not previously been exposed to subcutaneous T.vaginalis.

Looking at vaginal IgG response (Figure 12) at days 7,14 , 21 and 28 days of post intravaginal inoculation, only mice 
immunized and boosted with T.vaginalis showed an increase in antibody reactivity. A measurable but smaller vaginal IgG response was seen in the groups of mice which received a single immunization, but not in control groups. Vaginal IgA reactivity (Figure 13) in all the groups, immunized and unimmunized were not elevated, only the group of mice immunized and boosted showed a slight elevation. 
TABLE 7. Recovery of Trichomonas vaginalis in Mouse Vaginal Washes (Multiple Immunization and Protection)

\section{Days of Culture (positive)}

\begin{tabular}{|c|c|c|c|c|}
\hline Mouge Group & \pm 7 & \pm 14 & \pm 21 & +28 \\
\hline $\begin{array}{l}\text { Group } I(n=20) \\
T v+F C A->-56 \\
T v+F I A->-28\end{array}$ & $5 / 20$ & $5 / 20$ & $3 / 20$ & $1 / 20$ \\
\hline $\begin{array}{l}\text { Group } 2(n=16) \\
T v+F C A->-28\end{array}$ & $10 / 16$ & $9 / 15^{\star}$ & $7 / 14 *$ & $5 / 14 *$ \\
\hline $\begin{array}{l}\text { Group } 3(n=16) \\
I V+E I A->-28\end{array}$ & $10 / 16$ & $8 / 16$ & $7 / 16$ & $6 / 14 *$ \\
\hline $\begin{array}{l}\text { Group } 4(n=12) \\
\text { PBS + ECA-> -56 } \\
\text { PBS + FIA-> -28 }\end{array}$ & $11 / 12$ & $8 / 1.1 *$ & $6 / 11 *$ & $6 / 10^{*}$ \\
\hline $\begin{array}{l}\text { Group } 5(n=12) \\
\text { No Immunization }\end{array}$ & $9 / 11 *$ & $8 / 11^{\star}$ & $6 / 10^{\star}$ & $5 / 10^{*}$ \\
\hline $\begin{array}{l}\text { Group } 6(n=4) \\
\text { Neg. Control. }\end{array}$ & $0 / 4$ & $0 / 4$ & $0 / 4$ & $0 / 4$ \\
\hline
\end{tabular}

Tve T.vaginalis

* Changes in the denominator of the different columns are accounted for by unrelated death of mice. 


\section{FIGURE 10}

Multiple immunization and protection. Survivorship analysis estimating probability of recovery of T. vaginalis occuring over time.

- Group of mice immunized and boosted with $9 \times 10^{6} \mathrm{TV} / \mathrm{mL}$ in Freund's adjuvant at days -56 and -28 .

Group of mice immunized with $9 \times 10^{6} \mathrm{TV} / \mathrm{mL}$ in Freund's complete adjuvant at day -28 .

$\Delta$ Group of mice immunized with $9 \times 10^{6} \mathrm{Tv} / \mathrm{mL}$ in Freund's incomplete adjuvant at day -28 .

$\nabla$ Group of mice immunized and boosted with PBS.

$\checkmark$ Group of unimmunized mice (naive control). 


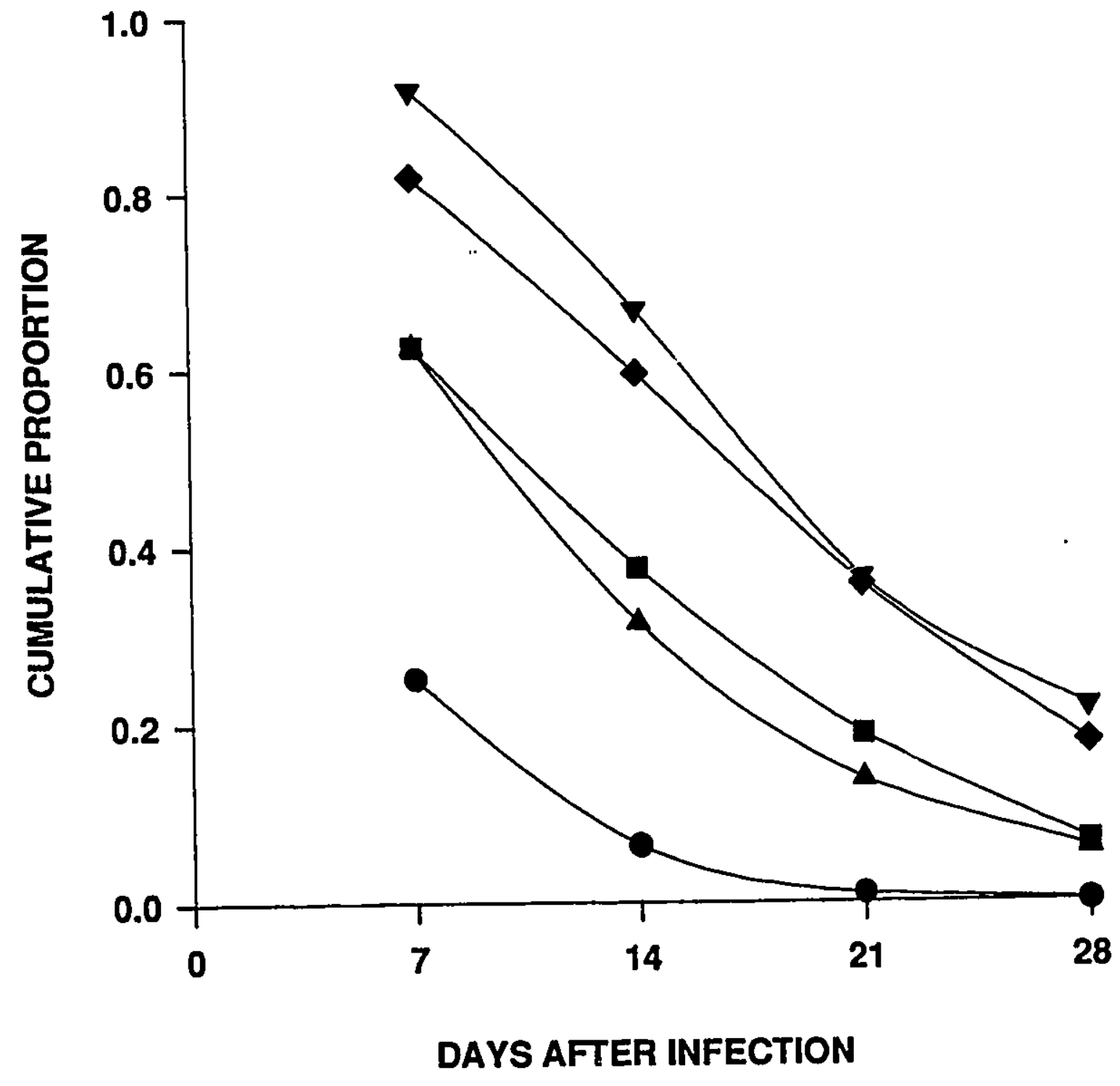




\section{FIGURE 11}

Wultiple immunization and protection. Kinetics of IgG serologic response to $T$.vaginalis as measured by ELISA.

Group of mice immunized and boosted with $9 \times 10^{6} \mathrm{Tv} / \mathrm{mL}$ in Freund's adjuvant, at days -56 and -28 respectively.

Group of mice immunized with $9 \times 10^{6} \mathrm{TV} / \mathrm{mL}$ in Freund's complete adjuvant at day -28 .

$\Delta$ Group of mice immunized with $9 \times 10^{6} \mathrm{TV} / \mathrm{mL}$ in Freund's incomplete adjuvant at day -28 .

$\nabla \quad$ Immunized and boosted with PBS. 


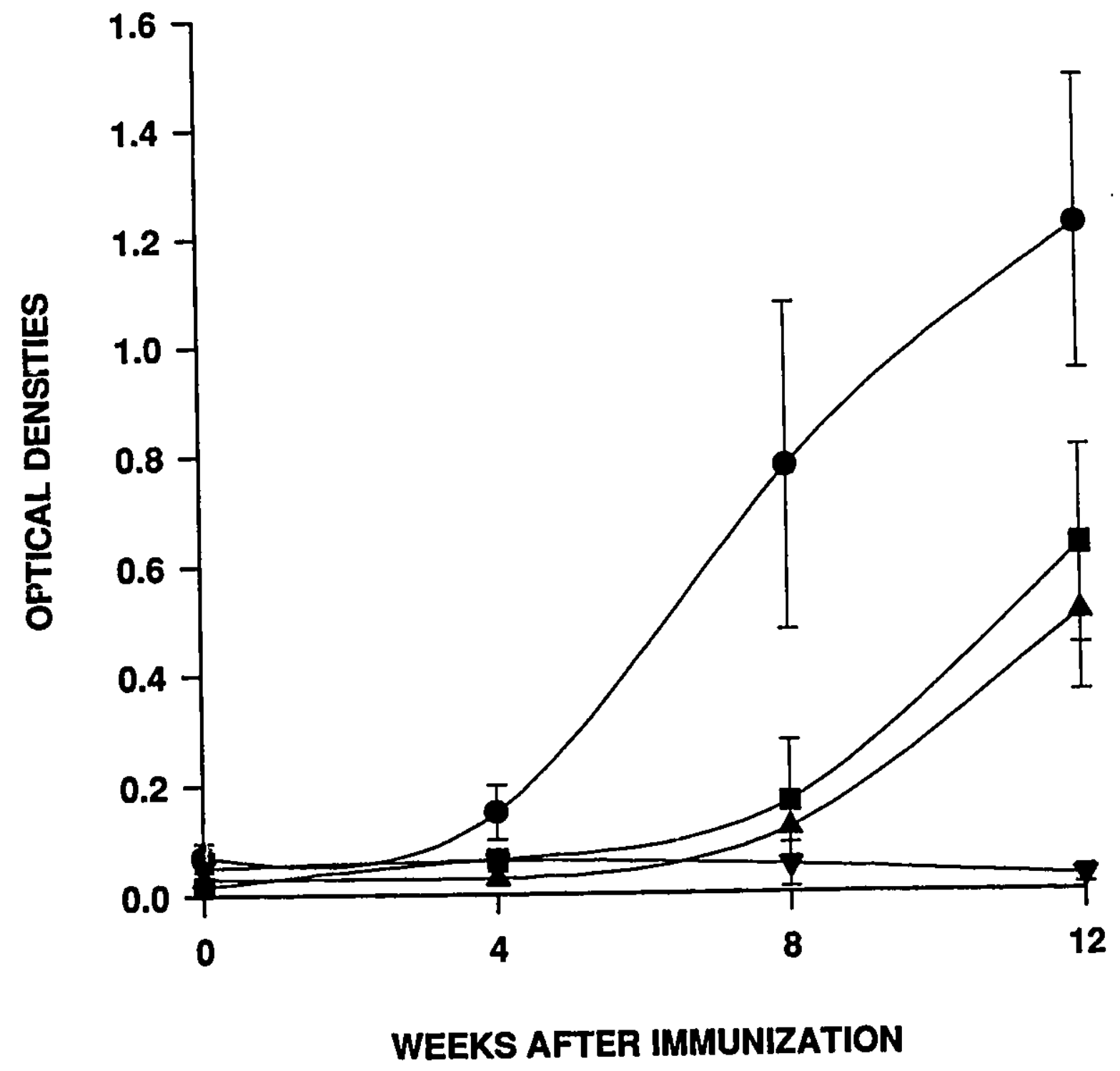




\section{FIGURE 12}

Multiple immunization and protection.

Kinetics of vaginal IgG response to $T$.vaginalis as measured by ELISA.

- Group of mice immunized and boosted with $9 \times 10^{6} \mathrm{TV} / \mathrm{mL}$ in Freund's adjuvant, at days -56 and -28 respectively.

a Group of mice immunized with $9 \times 10^{6} \mathrm{Tv} / \mathrm{mL}$ in Freund's complete adjuvant at day -28 .

$\Delta$ Group of mice immunized with $9 \times 10^{6} \mathrm{TV} / \mathrm{mL}$ in Freund's incomplete adjuvant at day -28 .

$\nabla$ Immunized and boosted with PBS. 


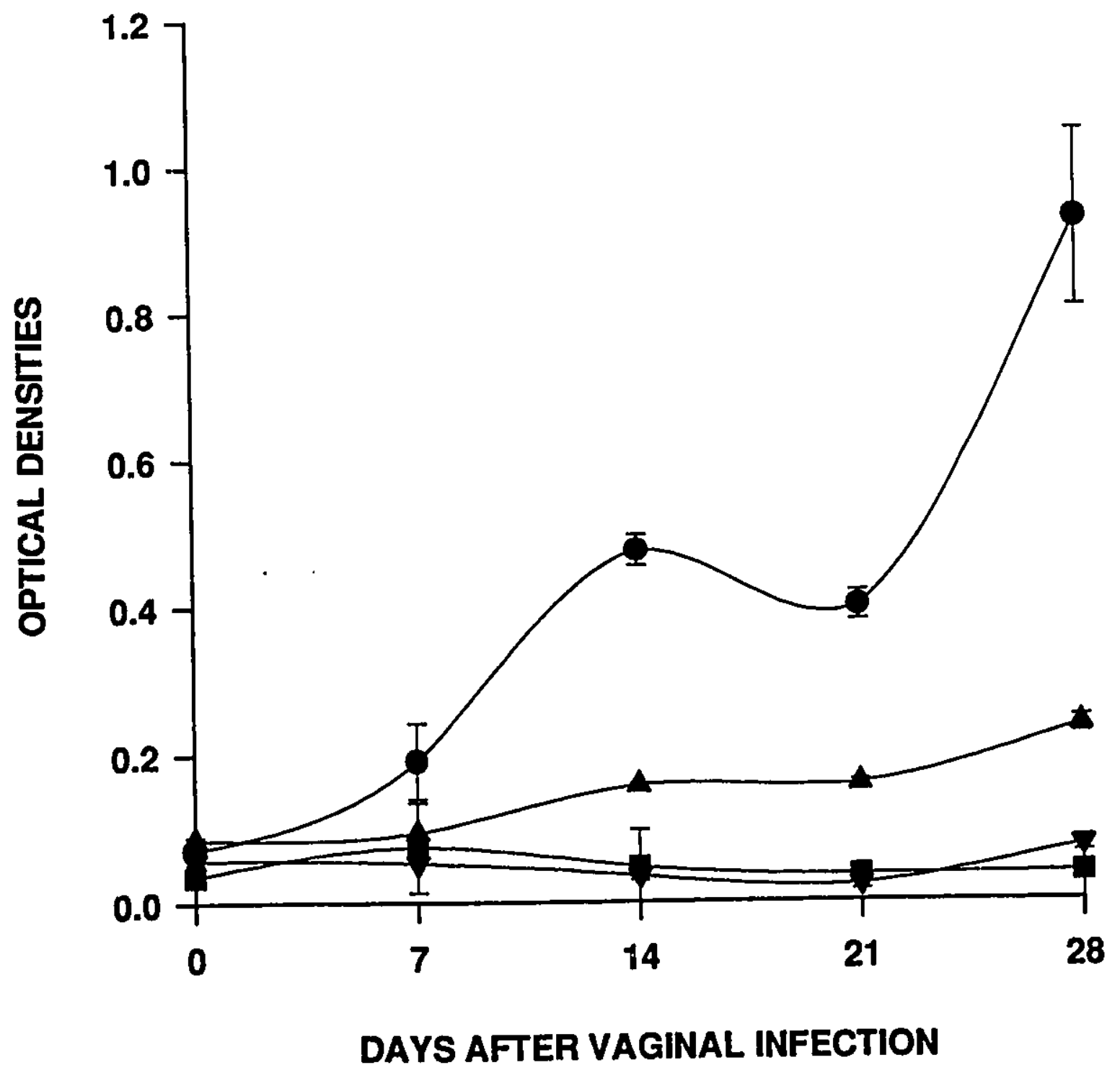


FIGURE 13

Multiple immunization and protection.

Kinetics of vaginal IgA response to $T$.vaginalis as measured by ELISA.

Group of mice immunized and boosted with $9 \times 10^{6} \mathrm{Tv} / \mathrm{mL}$ in Freund's adjuvant, at days -56 and -28 respectively.

- Group of mice immunized with $9 \times 10^{6} \mathrm{TV} / \mathrm{mI}$ in Freund's complete adjuvant at day -28 .

$\Delta$ Group of mice immunized with $9 \times 10^{6} \mathrm{TV} / \mathrm{mL}$ in Freund's incomplete adjuvant at day -28 .

$\nabla \quad$ Immunized and boosted with PBS. 


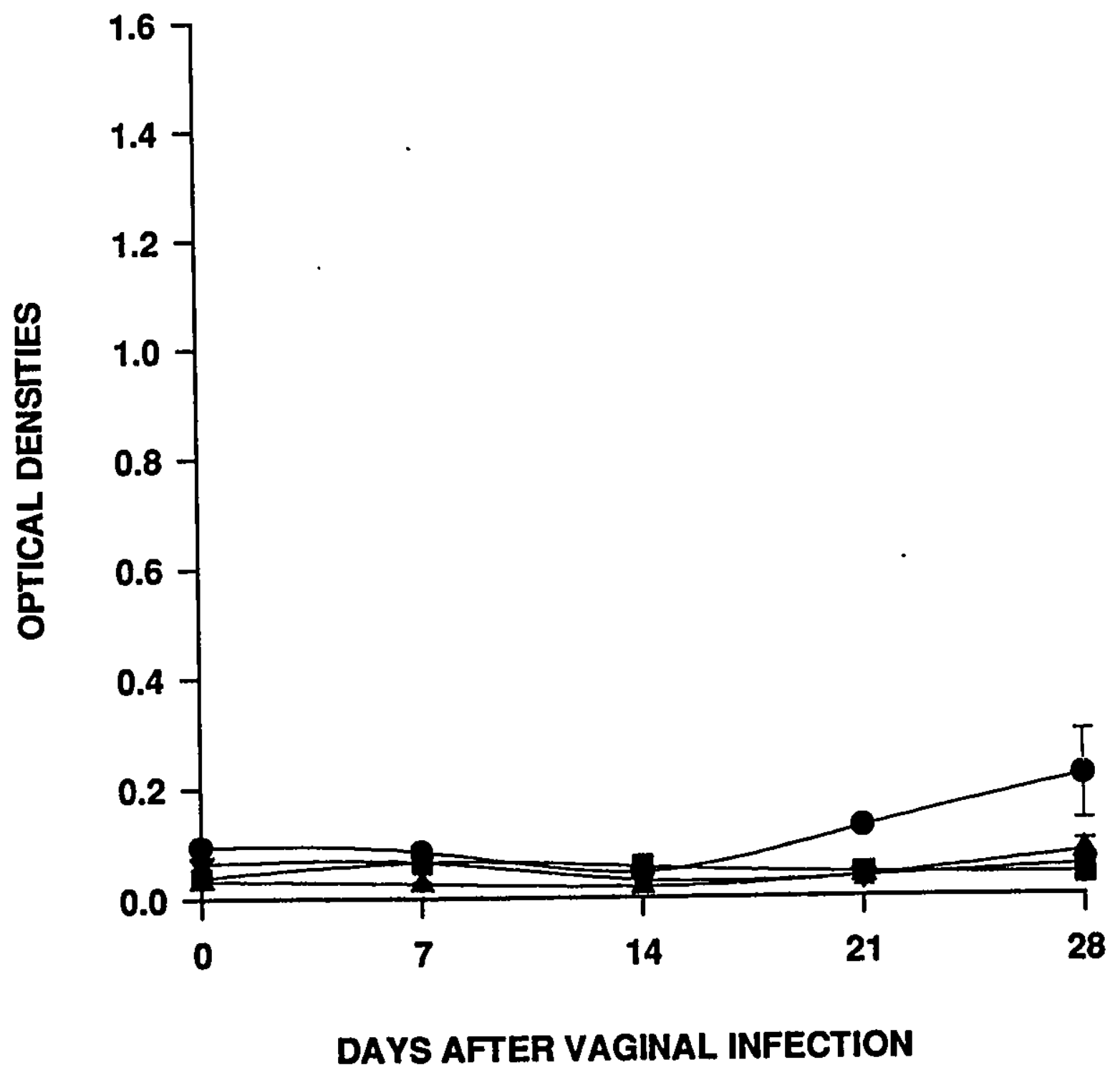




\section{METRONIDAZOLE TREATMENT \& RE-INFECTION:}

In order to determine whether vaginal infection and treatment induce protection, Balb/c mice were intravaginally infected with $T$.vaginalis and treated with metronidazole before the second intravaginal challenge. Table 4 depicts the recovery of $T$.vaginalis from the vaginal washes of infected and treated mice. Seven days after second intravaginal challenge 12 of 18 mice treated with metronidazole, 8 of the 9 mice treated with PBS and 7 of 8 untreated mice showed T.vaginalis culture positivity. Even after 28 days of post intravaginal challenge, $47 \frac{\circ}{\%}$ of metronidazole-treated mice, $55.5 \%$ mice treated with PBS and $62.5 \%$ of untreated mice were culture positive for T.vaginalis. Serum and vaginal T.vaginalis antibody response were not detected in these mice. 
TABLE 8. Recovery of Trichomonas vaginalis in

Mouse Vaginal Washes

(Metronidazole Treatment \& Protection)

\section{Days of Culture (positive)}

Mouge Group

Group $1(n=18)$

Drug-Metro

Group $2(n=9)$

PBS

Group $3(n=9)$

No Drug

Group $4(n=4)$

Neg. Control. $\pm 7$

$\pm 14$

$+21$

$+28$

$12 / 18$

$10 / 18$

$9 / 17 *$

$8 / 17$ *

$8 / 9$

$6 / 9$

$6 / 9$

$5 / 9$

$7 / 8$ *

$6 / 8 *$

$5 / 8 *$

$5 / 8 *$

$0 / 4$

$0 / 4$

$0 / 4$

$0 / 4$

* Changes in the denominator of the different columns are accounted for by unrelated death of mice. 


\section{DISCUSSION}

IMMONIZATION WITR T.VAGINALIS IN OUR MOUSE MODEL OF INFECTION

Despite the existence of chemotherapeutic agents, the incidence of trichomoniasis is increasing, and this has led to renewed interest in the immunological response of the host to this infection. Immune responses to infection with $T$.vaginalis have been described, including specific secretory antibody in vaginal secretion (Ackers et al., 1975), IgM and IgG antibody in serum (Manson, 1979; street et al., 1982), polymorphonuclear cell chemotaxis (Manson and Forman, 1980, 1982) and phagocytosis (Rein et al., 1980). Despite these responses, chronic infection with the parasite is common, and immunity to re-infection is poor (Ackers 1990). Also, information regarding host immunological responses to $T$.vaginalis remains inadequate.

The results presented in this study demonstrate that it is possible to achieve significant protection against $T$.vaginalis infection by subcutaneous immunization using whole cell T.vaginalis in an animal model. This study also proved that successful immunization can elicit an immune response that is stronger than or different from the immune response elicited by the natural infection. We achieved inducible immunity 
which provides protection from vaginal challenge to the trichomonad.

SIZE OF INOCULATION TO T.VAGINALIS FOR IMMUNIZATION:

Dose-response experiments were performed in order to determine the optimal dose of $T$.vaginalis for inducing immunization protection and anti-T.vaginalis antibodies. As a first step, recovery of $T$.vaginalis in mouse vaginal washes and trichomonad clearance from animals immunized with various doses of T.vaginalis suspended in adjuvant was compared with unimmunized animals. Mice that were immunized with the higher doses showed significant protection. Compared to the nonimmunized mice, mice that were immunized with the lowest dose also showed significant but a lower level of protection. This observation is also in agreement with the studies of Cripps et al. (1994) who showed the clearence of Pseudomonas aeruginosa infection was obtained with the highest immunizing dose.

Analysis of antibody response in serum and vaginal washes revealed that $T$.vaginalis specific IgG reactivity was significantly higher in mice immunized with the higher dose compared to the unimmunized mice but not in mice immunized with the lowest dose. Analysis on trichomonad clearence and specific antibody response revealed that some relationship exits between trichomonad clearance and specific antibody 
response. However, at a lower immunizing dose, T.vaginalis clearance from the vaginal wash samples were also observed, but to a lesser degree. This is the situation where the specific antibody response was not different from that in unimmunized mice. This study, suggests that antibodies provide some degree of protection, but there may be other mechanisms of protection that do not involve antibody. The exact function of IgG in serum and vaginal washes and the role it may play in protection is not clear. IgA antibody response in vaginal washes were also not elevated. We hypothesise that specific antibodies to $T$.vaginalis in conjunction with other immune processes may be involved in protection. Freund's complete adjuvant is a known stimulant of both cell-mediated and humoral responses (Cooper 1994) and Freund's incomplete adjuvant stimulates predominantly humoral immunity (Cooper 1994) suggesting that immunization with T.vaginalis suspended in these adjuvants induces both arms of the immune system. Therefore, cell-mediated immunity may also play an important role in protection against $T$.vaginalis infection.

\section{IMMUNIZATION REGIMIFN AND ROLE OF ADJUVANT:}

We examined the ability of immunization with a $T$.vaginalis whole cell antigen preparation to induce protective immunity against subsequent intravaginal challenge with $T$.vaginalis. The results suggested that immunization with Freund's adjuvant 
resulted in the induction of protective immunity against infection. Mice immunized with $T$.vaginalis in adjuvant developed high antibody response and were less likely to substain an infection after vaginal challenge compared to control groups.

The role of acquired immunity in human trichomoniasis is not clearly understood. As mentioned previously, chronic infection with the parasite is common, and immunity to re-infection is poor (Honigberg 1987; Chao et al., 1989). One could speculate that an explanation for the absence of a protective immune response in humans compared to our results as seen in mice is simpiy due to the fact that immune system of the mouse may respond to a different antigen or process the antigen in an entirely different manner than would the human. Interestingly, mice that were immunized and boosted with T.vaginalis, in the absence of adjuvant, did not show significant protection, compared to mice immunized with the adjuvant. Many immunologic studies have shown that previous exposure of the immune system to a pathogen enhances its ability to respond again to that antigen (Bouvet et al., 1994; Thapar et al., 1990; Cripps et al., 1994). In our study, immunization with an adjuvant elicited an immune response that is stronger than and/or different from the immune response elicited by natural infection or by immunization without adjuvant. This response induced protection from vaginal challenge with $T$.vaginalis. 
The mechanism of protection in the mouse model, whether cell mediated or humoral, will require much further work before it can be defined.

Examination of the antibody response in serum and vaginal washes in immunized mice following intravaginal challenge with $T \cdot v a g i n a l i s$ was the second aspect of this immunological investigation. A measurable serologic response was apparent in mice subcutaneously immunized and boosted with T.vaginalis suspended in Freund's adjuvant, prior to the intravaginal challenge with the trichomonad. Considerable IgG reactivity was detected after primary immunization, and a booster immunization led to a further elevation in the IgG antibodies. The reactivity of $T$.vaginalis specific IgG was even higher after vaginal infection. An interesting observation was the important role of adjuvant in enhancing the antibody response shown by the mice.

In human infection, it appears that the responsiveness of antibody in patients is not strong and the antibody titers are Low even in active T.vaginalis infection (Honigberg 1987; Alderete et al., 1991A; Chao et al., 1989). Our study demonstrated that it is possible to achieve a high response of T.vaginalis specific IgG in mice by booster immunization with T.vaginalis suspended in adjuvant. Adjuvants have been used to augment the immune response in experimental immunology as 
well as in practical vaccination for more than 60 years. The mode of action of adjuvants was summerized by Chedid (1985) as "(i) the formation of a depot of antigen at the site of inoculation which is slowly released; (ii) the presentation of antigen to immunocompetent cells; and (iii) the production of different lymphokines, such as various interleukins and tumor necrosis factor".

Many reports have been published confirming the existence of antitrichomonal antibody in human cervicovaginal secretions by various immunological methods and T.vaginalis specific IgG and IgA were reported in a majority of reports (Street et al., 1982; Peter et al., 1988; Su-Lin 1982; Ackers et al., 1975; Alderete, 1984). However, there is little evidence that it results in protective immunity. Alderete et al., (1991 A) reported that in some cases, trichomoniasis was not associated with detectable vaginal antibody. Attempts to detect antibody in vaginal washes showed that only the group of mice immunized and boosted with $T$.vaginalis suspended in Freund's adjuvant prior to infection showed a significant IgG response upon infection. The IgA EIA reactivity was not as elevated as the IgG. This result is in agreement with previous studies, reporting the induction of antibodies in genital secretions by a conventional systemic route of immunization (Bouvet et a., 1994; Thapar et al., 1990). Our study observed IgG and IgA titres in vaginal washings after immunizations via 
subcutaneous route with $T$ vaginalis in combination with Freund's adjuvant and suggest that immunization might have an important influence on secretory immunoglobulin at mucosal surfaces.

We have determined that immunization with $T$.vaginalis in combination with Freund's adjuvant induced protection against vaginal infection by $T$.vaginalis and an enhanced antibody reactivity in serum and vaginal washes. However, an increased antibody response may not be the only explanation for the protective effect seen in this study. As well, the exact function of these antibodies and the role they may play in protection is not clear. In an earlier report, Martinotti and colleagues (1977) found that protection in mice does not appear to correspond to serum antibody titre. A similar situation exists in human $T$.vaginalis infections. Although evidence exists for both serum and vaginal antitrichomonal antibodies in women infected with T.vaginalis (Ackers et al., 1978), neither appeared to protect against reinfection with the trichomonad. However, Honigberg (1970) summarized a report suggesting that serum from infected patients protected mice against $T$.vaginalis infection. The mechanism for this effect was not completely understood. In-vitro studies of Alderete and Kasmala (1986) have also shown that monoclonal antibodies raised against $T$.vaginalis can kill the antigenpositive parasite independent of complement activation. 
However, sera from infected patients have been shown to exhibit complement mediated lytic activity on trichomonads in cultures (Holbrook et al., 1982). Passive immunization experiments with mouse sera could be performed to determine to what extent humoral immunity is involved in the observed protection.

It is generally accepted that $I g A$ is an important immunoglobulin in many mucosal secretions in humans and other animals and that, secretory IgA plays an important role in immunity to certain microbial infections of the respiratory and gastrointestinal tracts (Goldblum 1990; Thaper et al.,1990). Chipperfield and Evans (1972) noted an increase of IgA-, IgG-, and IgM- containing plasma cells in endocervical tissues from women with gonorrhea, trichomoniasis, and candidiasis. Plasma cells of the IgM class were more prominent in trichomoniasis than in the other two infections. Unexpectedly, in our study, the elevation of the IgA antibody response to $T$.vaginalis did not rise as much as the serum IgG antibodies and vaginal IgG antibodies. Possible explanations for the low rate of IgA detection in the vaginal washes in the present study as compared to that of Ackers et al. (1975) and Su-Lin (1982), may be: "i) low IgA antibody levels are present in the vaginal washes that can be demonstrated by the assay used in this study; ii) IgA may be produced by the host only during a certain period in the course of infection and the low 
IgA could be a result of the adsorption of the antibody by the organisms". However, there is little evidence that it is harmful or inhibitory to the parasite. Ackers et al. (1975) suggested that low parasite counts in vaginal secretions were associated with the presence of antitrichomonad antibody. Chipperfield and Evans (1972) suggested that the typical absence of the urogenital trichomonad from the cervical mucosa might be caused by the production of antibodies, such antibodies could prevent invasion of the uterus and fallopian tubes by T.vaginalis.

\section{MULTIPLE IMAONIZATION AND PROTECTION:}

In order to understand the importance of boosting in inducing protective immunity and anti-T.vaginalis antibodies, multiple immunization experiments were performed. Looking at the recovery of $T$.vaginalis in mouse vaginal washes and trichomonad clearance, we have seen that, mice which were immunized and boosted prior to the intravaginal challenge were less likely to develop infection and had a significant rate of trichomonad clearance, compared to the mice which received a single immunization or no immunization. In human trichomoniasis previous exposure to T.vaginalis does not appear to convey any protection. Repeated infection with T.vaginalis may occur without significant difference in either duration of infection or intensity of symptoms as one might 
expect if there were a specific immune response (Graves and Gardner 1993; Chao et al., 1989). These results underscore the importance of a booster immunization protocol for the development of protective immunity in our mouse model. Examination of the antibody response in serum and vaginal washes revealed high response of IgG antibodies in mice immunized and boosted with T.vaginalis, prior to intravaginal challenge with the trichomonad. Serum IgG antibodies were also raised but to a lesser degree in mice which received only a single dose of immunization, compared to the control mice. However, the level of protection and response of serum IgG in these single immunization animals was found to be much lower, compared to the immunized and boosted animals. Boosting did not alter vaginal IgA but did influence vaginal IgG response.

Protection against experimental $T$.vaginalis infection in mice can be elicited by subcutaneous immunization with whole cell trichomonad. Enhanced protozoal clearance and also pronounced antibody response were seen in immunized and boosted animals, however the mechanism by which a subcutaneous immunization leads to protection is not clear. The role of antibody in trichomonad clearence from vaginal infection is far from clear. Protection due to antibody has been demonstrated in some systems (Honigberg 1970), but not in others (Martinotti et al., 1977). The role played by cell mediated immunity in protection is also important to 
consider.

An explanation for the low rate of IgA detection in the vaginal washes, in light of studies with the Neisseria gonorrhoeae and Streptococcus sanguis (Pault et al., 1977) is that production of IgA protease reduces the IgA activity. proteinases degrading antibodies have also been found in protozoan parasites (Mckerrow et al., 1993). T.foetus, the causative agent of fetal. wastage in cattle, is known to secrete cysteine proteinases that digest the heavy chain of host IgG (Talbot et al., 1991). A recent report also describes human IgA heavy chain degradation by Entamoeba histolytica, another mucosal protozoan parasite (Kelisall and Ravdin 1993). IgG and IgA antibodies to immunogenic $T$.vaginalis surface proteins and to proteinases have been found in sera and vaginal washes of patients with trichomoniasis (Alderete et al., 1991 A and B; Bozner et al., 1992; Sharma et al., 1991). Very recently, Provenzano and Alderete (1995) reported that $T$.vaginalis cysteine proteinases are capable of degrading human immunoglobulins and suggested its possible role in immune evasion and in predisposing the urogenital mucosa to coinfection and pathogenesis. It is noteworthy that no vaginal antibody is detected in some women with trichomoniasis (Alderete et al., $1991 \mathrm{~A}$ ). This lack of detection of antibody may be directly or indirectly a result of trichomonal Igdegradation activity that may be associated with the 
trichomonal proteinases.

Previous studies also demonstrate that the mucosal immune response in the genital tract is affected by female hormones (Wira and Sullivan 1985; Wira and Sandoe 1980). Studies of Wira and Sullivan (1985), documented that estrogen and progesterone can lower vaginal antibody and secretory antibody component levels in cervical and vaginal secretions. Further studies are needed to identify the role, if any, these factors may play in lowering antibody response in the vaginal washes. In our study, the vaginal washes were pooled from mice in each group because of the small quantities of washes. Thus, washes obtained could contain antibodies from both immune and nonimmune mice. For an accurate detection, analysis of the vaginal washes from individual mice would be necessary.

Despite identical procedures in the immunization, boosting, administration of estrogens, inoculation of I.acidophilus and inoculation of T.vaginalis, mice showed different response to the antibody reactivity and varied susceptibility to infection. The variations observed in the mice also appear in natural infection. Individual host response to infectious agents is dependent on many factors such as properties of antigen, dose of antigen, site of exposure, hormonal levels, and ongoing immune response in the host (Honigberg 1987). 
Regardless of immunization and infection, the death of mice seen in each group was considered as a consequence of the experimental manipulations and associated stress and did not reflect the type of intervention used.

Protection was not. demonstrated in mice which were infected vaginally, treated with metronidazole and then reinfected vaginally. This suggests that the response to infection and immunization protection could be associated with the route of immunization. These results also underscore the importance of an immunization protocol for the development of protective immunity in our mouse model. 


\section{CONCLUSION}

In conclusion, we have found that subcutaneous immunization with T.vaginalis appears to induce protection from intravaginal challenge with T.vaginalis. Mice that had received subcutaneous immunization and boosting with T. vaginalis prior to intravaginal challenge were significantly less likely to develop infection and had a significantly higher rate of trichomonad clearence, compared to the mice which received only a single immunization or no immunization. A measurable serum and vaginal antibody response was also apparent in mice subcutaneousiy immunized with $T$.vaginalis prior to vaginal infection. However, the mechanism by which the immunization mediates this protection is not clearly understood. The role of cell mediated immunity may be a factor in the protective response to $T$.vaginalis infection. Passive immunization experiments with anti-T.vaginalis mouse sera could be performed to determine the extent of the role of systemic humoral immunity in protection.

These preliminary immunological studies have opened the door to further investigations into the immune response to T.vaginalis infection. The successful protective immune response. seen in mice suggests tine possibility to apply a similar approach studies in to the development of a human vaccine. 


\section{IIST OF REFERENCES}

ABUREL, E., G. ZERVOS, V.TITEA, and S. PANA 1963. Immunological and therapeutic investigations in vaginal trichomoniasis. Rom. Med. Rev. 7:13-19.

ACKERS, J.P., W.H.R. ZUMSDEN, R.D. CATTERALL, and R. COYLE 1975. Antitrichomonal antibodies in the vaginal secretions of women infected with $T$. vaginalis. Br. J. Vener. Dis. 51: 319-323.

ACKERS, J.P., R.D. CATTERALL, W.H.R. LUMSDEN, A. MCMILLAN. 1978. Absence of detectable antibody in genitourinary tract secretions of male contacts of women infected Trichomonas vaginalis. Br. J. Vener. Dis. 54: 168-171.

ACKERS, J.P.1990. Immunologic aspects of human trichomoniasis. In B.M. Honigberg (ed.), Trichomonads parasitic in humans. Springer Verlag, New York. p 36-52.

ALDERETE, J.F. 1984. Enzyme linked immunoabsorbent assay for detecting antibody to Trichomonas vaginalis: use of whole cells and acqueous extract as antigen. $\mathrm{Br}$. J. Vener. Dis. 60: 164-170.

ALDERETE, J.F. and E. PEARLMAN. 1984. Trichomoas vaginalis cytotoxicity to cell culture monolayers. Br. J. Vener. Dis. 60: 99-105.

ALDERETE, J.F., L. SUPRUN-BROWN, I. KASMALA, J. SMITH, and $M$. SPENCE. 1985. Heterogeneity of Trichomonas vaginalis and discrimination among.trichomonal isolates and subpopulations with sera of patients and experimentally infected mice. Infect. Immun. 49: 463-468.

ALDERETE, J.F. and KASMALA 1986. Monoclonal antibody to a major glycoprotein immunogen mediates differential complement independent lysis of Trichomoas vaginalis. Infect. Immun. 53: 697-699.

ALDERETE, J.F., L. KASMALA, E. METCALFE, and G.E. GARZA. 1986. Phenotypic variation and diversity amoung Trichomonas vaginalis isolates and correlation of phenotype with trichomonal virulence determinants. Infect. Immun. 53: 285293.

ALDERETE, J.F. 1987. Biology and virulence of Trichomonas vaginalis and Trichomoniasis. ACTA, Universitatis Carolinae Biologica 30, (1986): 357-372. 
ALDERETE, J.F. E.NEWTON, C.DENNIS, and K.A. NEALE. 1991. The vagina of women infected with Trichomonas vaginalis has numerous proteinases and antibody to trichomonal proteinases. Genitourin. Med. 67: 469-474.

ALDERETE, J.F., E. NEWTON, C. DENNIS and K.A. NEALE. 1991. Antibody in sera of patients infected with Trichomonas vaginalis is to trichomonad proteinases. Genitourin. Med. 67: $331-334$.

ARROYO, R. and J.F. ALDERETE. 1989. Trichomonas vaginalis proteinase activity is necessary for parasite adherence to epithelial cells. Infect. Immun. 57: 2991-2997.

BAREFOOT, S.F., and T.R. KLAENHAMMER. 1984. Purification and characterization of the Lactobacillus acidophilus bacteriocin lactacin B. Antimicrob. Agents Chemother. 26(3): 328-334.

BOUVET, J.P., B. LAURENT, P. RENE and P. JACQUES 1994 . Immunoglobulin $G$ antibodies in human vaginal secretions after prenatal vaccination. Infect. Immun. 62(9): 3957-3961.

BOZNER, P., A. GOMBOSOUA, M. VALENT, P. DEMES and J.F. ALDERETE. 1992. proteinases of Trichomonas vaginalis: antibody response in patients with urogenital trichomoniasis. parasitol. 105: 387-391.

BRAMLEY, M. 1976. Study of female babies of women entering confinement with vaginal trichomoniasis. Br. J. Vener. Dis. 52 : 58-62.

BROWN, M.T. 1972. Trichomoniasis. Practitioner 209: 639-644.

CAPPUCCINELLI, P., C. IATTES, I. CAGLIANI, and A.N. PONZI. 1974. Features of intravaginal Trichomonas vaginalis infection in the mouse and the effect of aestrogen treatment and immunodepression. Giornale di Batteriologia, Virologia ed Immunologia 67 : 31-40.

CHAO, D. , S.R. WONG, and HEUNG-TAT, N.G. 1989. Suppression of humoral immune response in mice by antigens derived from $T$. vaginalis. Proc. Natl. Sci. Counc. B. Roc. 13(3): 171-175.

CHEDID, L. 1985. Adjuvants of immunity. Ann. Immunol. (Inst. Pasteur). 136D: 283.

CHIPPERFIELD, E.J. and B.A. EVANS. 1972. The influence of local infection on immunoglobulin formation in the human endocervix. Clin. Exp. Immunol. 11: 219-223.

COGNE, M., P. BRASSEUR, and J.J. BALLET. 1985. Detection and characterization of serum antitrichomonal antibodies in 
urogenital trichomoniasis. J. Clin. Microbiol. 21(4): 588592 .

COOK, R. L., G.W. TANNOCK, and R.J. MEECH. 1984. The normal microflora of the vagina. Proceedings of the University of Otago Medical School, 62; 72-4.

COOMBS, G.H., and M.J. NORTH, 1983. An analysis of the proteinases of Trichomonas vaginalis by polyacrylamide gel. electrophoresis. Parasitol. 86: 1-6.

COOMBS, G.H., A.F. BREMNER, D.J. MARKHAM, V.S. LATTER, M.A. WALTERS, and M.J. NORTH. 1986. Intravaginal growth of Trichomonas vaginalis in mice. Acta Universitatis Carolinae Biologica. 30: 387-392.

COOPER, P.D. 1994. The selective induction of different immune responses by vaccine adjuvants. In strategies in vaccine Design, edited by Gordon L. Ada. R. G. Landes Company.

p. 125-158

CORBEIL, I.B., A. CHATTERJEE, L. FORESMAN, and J.A. WESTFALI. 1985. Ultrastructure of cyclic changes in the murine uterus, cervix and vagina. Tissue and Cell. 17: 53-68.

COTCH, M.F. Effect of Trichomonas vaginalis carriage on pregnancy outcome. Published Abstract. Presented at the $9^{\text {th }}$ International Society for STD Research. Banff, Alberta. october 1991.

CRIPPS, A.W., M.L. DUNKLEY and R.I. CLANCY. 1994. Mucosal and systemic immunizations with killed Pseudomonas aeruginosa protect against acute respiratory infections in rats. Infec. Immun. 62: 1427-1436.

DIAMOND, I.S., D.R. HARLOW, and C.C. CUNNICK. 1978. A new medium for the axenic cultivation of Entamoeba histolytica and other Entamoeba. Trans. R. Sec. Trop. Med. Hyg. 72: 431-432.

DRAPER, D., W. JONES, R.RICHTER, J. JAMES, J. TODD, and J . MCGREGOR. Effect of Trichomonas vaginalis on fetal membranes bursting strength. Pulished Abstract. Presented at the $9^{\text {th }}$ International Society for STD Research. Banff, Alberta. october 1991.

DYKERS, J.R. 1975. Single dose metronidazole for trichomonal vaginitis. N. Eng. J. Med. 293: 23-24.

DEMES, P., A. GOMBOSOVA, M. VALENT, and A. JANOSKA. 1987. Factors of nonspecific immunity in human trichomoniasis. ACTA Universitatis Carolinae-Biologica 30: (1986) : 337-342. 
FAIR, W.R., COUCH, JL, WEHNER, N. Prostatic antibacterial factor: identity and significance. Urology 7: 169-177, 1976.

FOUTS, A.C. and S.J. KRAUS. 1980. Trichomonas vaginalis: Reevaluation of its clinical presentation and laboratory diagnosis. J. Infect. Dis. 141: 137-143.

FOX, R.R. and C.W. LAIRD. 1970. Sexual cycles. In E.S.E. Hafez (ed.), Reproduction and breeding techniques for laboratory animals. Lea and Febiger, Philadelphia. P. 107122 .

GARBER, G.E., E.M. PROCTOR, and W.R. BOWIE. 1986. Immunogenic proteins of Trichomonas vaginalis as demonstrated by the immunoblot technique. Infect. Immun. 51(1): 250-253.

GARBER, G.E., L. SIBAU, R. MA, E.M. PROCTOR, C.E. SHAW and W.R. BOWIE. 1987. Cell culture compared with broth for detection for Trichomonas vaginalis. J. Clin. Microbiol. 25(7) : 1275-1279.

GARBER, G.E., L.T. LEMCHUK-FAVEL, and W.R. BOWIE. 1989a. Isolation of a cell-detaching factor of Trichomonas vaginalis. $\mathrm{J}$. Clin. Microbiol. 27(7): 1548-1553.

GARBER, G.E. and L.T. LEMCHUK-FAVEL. 1988b. Characterization and purification of extracellular proteases of Trichomonas vaginalis. Can. J. Microbiol. 35: 903-909.

GARDNER, W.A., D.E. CULBERSON, J.M. SCIMECA, A.G. BRADY, F.F. PINDAR and C.R. ABEE. 1987. Experimental genital trichomoniasis in the squirrel monkey (Saimiri sciureus). Genitourin. Med. 63: 188-191.

GIORGI, A., TORRIANI, S. F. DELLAGLO, G. BO, E. STOLA, L. BERNUZZI. 1987. Identification of vaginal lactobacilli from asymptomatic women. Microbiologica. 10: 377-384.

GILLILAND, S.E., and M.L. SPECK. 1977a. Antagonistic action of L.acidophilus toward. intestinal and foot borne pathogens in associative cultures. J. Food Protect. 40: 820-823.

GILLILAND, S.E., and M.L. SPECK. 1977b. Instability of L.acidophilus in yogurt. J. Dairy Sci. 9: 1394-1398.

GILLIN, F.D. and A. SHER. 1981. ACtivation of the alternative compliment pathway by Trichomonas vaginalis. Infect. Immun. 34: 268-273.

GOMBOSOVA, A., P. DEMES and M. VALENT. 1986. Immunotherapeutic effect of the Lactobacillus vaccine, Solco-Trichovac, in trichomoniasis is not mediated by antibodies cross reacting 
with Trichomonas vaginalis. Genitourin. Med. 62: 107-110.

GoLBLUM, R.M. 1990. The role of IgA in local immune response. $\mathrm{J}$. Clin. Immun. $10(6): 64 \mathrm{~s}-71 \mathrm{~s}$.

GORDON I. ADA. 1994. Vaccination strategies to control infections: An Overview. In Strategies in vaccine Design, edited by Goron L.A. R.G. Landes Company. p. 1-16.

GORELI, T.E. 1985. Effect of culture medium iron content on the biochemical composition and metabolism of Trichomonas vaginalis. J. Bacteriol. 161: 1228-1229.

GRAVES ALLISON and GARDNER, A.W. 1993. Pathogenicity of Trichomonas vaginalis. Clin. Obstet. Gynecol.36:145-152.

HAGER, W.D., BROWN, S.T., S.J. KRAUS, G.S. KLERIS, G.J. PERKINS, and M. HENDERSON. 1980. Metronidazole for vaginal trichomoniasis: Seven days vs single dose regimen. JAMA. 244: 1219-1220.

HANNA, N.F., D. TAYLOR-ROBINSON, M. KALIODIKI-KARAMANOLI, J.R.W. HARRI's and I.R. 'MCFADYEN. 1985. The relation between
vaginal $\mathrm{pH}$ and the microbiological status in vaginitis. Br. $\mathrm{J}$. Obstet. Gynecol. 92: 1267-1271.

HEINE P. AND MCGREGOR A.J. 1993: Trichomonas vaginalis. A reemerging pathogen. Clin. Obstet. Gynecol. 36(1): 137-144.

HILLIER, L.S., M.A. KROHN, S.J. KLEBANOFF AND O.A ESCHENBACH. 1992. The relationship of Hydrogen Peroxide Producing Lactobacilli to Bacterial Vaginosis and Genital Microflora in pregnant women. Obstet.Gynecol. $79(3): 369-373$.

HOLBROOK, T.W., BOACKLE R.J., VESELY J. AND PARKER B.W. 1982. Trichomonas vaginalis: alternative pathway activation of complement. Trans Royal Soci. Trop. Med Hygi. 76: 473-475.

HOLST, E., B. WATHNE, B. HOVELIVES and P.A. MARDH. 1987. Bacterial vaginosis: Microbiological and clinical findings. Euro. J. Clin. Micro. 6: 536-541.

HONIGBERG, B.M. 1970. Trichomonads In G.J. Jackson. R.Herman and L.Singer(eds), Immunity to parasitic animals, vol.2. Appleton-Centory- Crofts, NewYork. pp 469-550.

HONIGBERG, B.M. 1978. Trichomonads of importance in human medicine. In Parasitic Protozoa Vol. 2. Edited by J.P. Kreier. Academice Press, New York. pp. 275-454.

HONIGBERG, B.M., P.K. GUPTA, M.R. SPENCE, J.K. FROST, K. KUCZYNSKA, I. CHÓROMANSKI, and A. WARTON. 1984. Pathogenicity 
of Trichomonas vaginalis. Cytopathologic and histopathologic changes of the cervical epithelium. obstet. Gynecol. 64(3): 179-184.

HONIGBERG, B.M. 1987. Immunology of Trichomonads, with emphasis on Trichomonas vaginalis. A Review ACTA Univeritatis Carolinae - Biologica 30, (1986). 10: 321-336.

JARECKI-BLACK, J.C., W.B. LUSHBAUGH, I. GOLOSOV and A.3. GLASSMAN. 1988. Trichomonas vaginalis: Preliminairy characterization of a sperm motility inhibiting factor. Ann. Clin. Lab. Sci. $18(6): 484-489$.

JIROVEC, $O$. and M.PETRU. 1968. Trichomonas vaginalis and trichomoniasis. Adv. Parasitol. 6: 117-188.

JORMA PAAVONEN. 1983. Physiology and Ecology of the vagina. Scand. J. Infect. Dis., suppl. 40: 31-35.

KAZANOWSKA, W., K. KUCZYNSKA, and R. SKRZYPIEC. 1983. pathology of Trichomonas vaginalis infection in experimental animals. Wiad. Parazyt. 29: 63-66.

KEISALL, B.L. and J.I. RAUDIN. 1993. Degradation of human IgA by Entamoeba histolytica. J. Infect. Dis. 168: 1319-1322.

KLEBANOFF; S.J., S.L. HILIIER, D.A. ESCHENBACH, and A.M. WATTERSDORPH. 1991. Control of the microbial flora of the vagina by $\mathrm{H}_{2} \mathrm{O}_{2}$ - generating Lactobacilli. J. Infect. Dis. 164 : 94-100.

KLEBANOFF, S.J., and COOMBS, R.W. 1991. Virucidal effect of $L$. acidophilus on HIV type-I: possible role in heterosexual transmission. J. Exp. Med. 174: 289-292.

KOCH, R.L., B.B. BEAULIEU, E.J.T. CHRYSTAL, and P. GOLDMAN. 1981. A metronidazole metabolite in human urine and its risk. Science 211; $398-400$.

KRIEGER. J.N. 1981. Urologic aspects of trichomoniasis. Invest. Urol. 18: 411-417.

KRIEGER, J.N., M.R. TAM, and C.E. STEVEN. 1988. Diagnosis of trichomoniasis. Comparison of conventional wet mount examination with cytologic studies, cultures and monoclonal antibody staining of direct specimens. JAMA. 259: 1223-1227.

KRIEGER, J.N. and M.F. REIN. 1982. Canine prostate secretions kill Trichomonas vaginalis. Infect. Immun. 37:77-81.

KRIEGER, J.N. and M.F. REIN. 1982. Zinc sensitivity of 
Trichomonas vaginalis: In-vitro studies and clinical implications. Infect. Dis. 146:341-345.

KRIEGER, J.N., J.I. RAVDIN and M.F. REIN. 1985. Contact dependant cytopathogenic mechanisms of Trichomonas vaginalis. Infect. Immun. 50(3): 778-786.

KRIEGER, J.N. 1990. Epidemiology and clinical manifestations of urogenital trichomoniasis in men. In B.M. Honigberg (ed.), Trichomonads parasitic in humans. Springer-Verlag, New York. pp. 235-245.

KUBERSKI, T. 1978. Evaluation of the indirect hemmagglutination technique for the study of Trichomonas vaginalis infections, particularly in men. Sex. Trans. Dis. 5: 97-102.

KUBERSKI, T. 1980. Trichomonas vaginalis associated with non-gonococcal urethritis and prostatis. Sex. Tras. Dis. 7: $135-136$.

KULDA, J., M. VOJTECHOVSKA, J. TECHEZY, P. DEMES, and E. KUNZOVA. 1982. Metronidazole resistance of Trichomonas vaginalis as a cause of treatment failure in trichomoniasis. Br. J. Vener. Dis. 58: 394-399.

KURNATOWSKA, A., and A.KOMOROWSKA.1990.Urogenital Trichomoniasis in children. In Trichomonads parasitic in Humans, B.M. Honigberg (ed). Springer-Verlag. NewYork, p.246 to 273 .

LAGA, M., A. MANOKA, M. KIVUVU, B. MALELE, M. TULIZA, N. NZILA, J. GOEMAN, F. BEHETS, V. BATTER, M. ALARY, W.L. HEYWARD, R.W. RYDER and P. PIOT. 1993. Non-ulcerative sexually transmitted disease as risk factors for HIVtransmission in women: results from a cohort study. AIDS. 7: 95-102.

LAGA, M. M. ALARY, N. NZILA, A.T. MANOKA, M. TULIZA, F. BEHETS, J. GOEMAN, M. St. LOUIS and P. PIOT. 1994. Condom promotion, sexually transmitted diseases treatment, and declining incidence of $\mathrm{HIV}-\mathrm{I}$ infection in female Zairian sex workers. Lancet. 344: 246-248.

LANDOLFO. S., G. MARTINOTTI, P. MARTINOTTI, and G. FURNI. 1980. Natural cell mediated cytotoxicity against Trichomonas vaginalis in the mouse. J. Immun. 124: 508-514.

LARSEN, B., MARKOVETS, A.J. AND GALASK R.P 1976. Quantitative alterations of the genital microflora of female rats in relation to the estrous cycle. J. Infect. Dis $134: 486$. 
LARSEN, B. and R.P. GALASK. 1980. Vaginal microbial flora: Practical and theoretic relevance. Obstet. Gynecol. 55(5): $100 \mathrm{~s}-113 \mathrm{~s}$.

IARSEN, B. and R.P. GALASK. 1982. Vaginal microbial floara: Composition and influences of host physiology. Ann. Internal Med. 96: $926-930$.

LARSEN, 1993. Vaginal Elora in health \& Disease. Clin. Obstet. Gynecol. 36(1): 107-121.

LEGATOR, M.S., T.H. CONNER, and M. STOECKEL. 1975. Detection of mutagenic activity of metronidazole and nitroimidazole in body fluids of humans and mice. Science 188: 1118-1119.

LEHKER, M.W., and J.F. ALDERETE. 1990. Properties of Trichomonas vaginalis grown under controlled conditions. Genito. Med. 66: 193-199.

LEHKER, M.W., R. ARROYO, and J.F. ALDERETE. 1991. The regulation by iron of the synthesis of adhesins and cytoadherence levels in the protozoan Trichomonas vaginalis. J. Exp. Med. $174(2): 311-318$.

LOCKWOOD, W.C., M.J. NORTH and G.H. COOMBS. 1985. Purification and characterization of proteinases of parasitic protozoan Trichomonas vaginalis. Biochem. Soc. Trans. 13: 336 .

LORENZ, V. and H. RUTTGERS. 1983. Clinical experience using Solco-Trichovac in the treatment of Trichomonas infection in women. Gynak. Rasch. 23: suppl. 2, pp. 64-71.

LOSSICK, J.G., 1990. Epidemiology of Urogenital Trichomoniasis.

LOSSICK and KENT. 1991. Trichomoniasis: Trends in diagnosis and management. Am. J Obst. Gynecol. 165: 1217-1222.

MANSON, P.R., H. SUPER, P.J. FR.IPP. 1976. Comparison of four techniques for the routine diagnosis of Trichomonas vaginalis infection. J. Clin. Pathol. 29: 154-157.

MANSON, P.R. 1979. Serodiagnosis of Trichomonas vaginalis infection by the indirect fluorescent antibody test. $J$. of Clin. Pathol. 32: 1211-1215.

MANSON, P.R. and L. FORMAN, 1980. In-vitro attraction of polymorphonuclear leucocytes by Trichomonas vaginalis. $\mathrm{J}$. Parasitol. 66: 888-892.

MANSON, P.R. and FORMAN, L. 1982. Polymorphonuclear cell 
chemotaxis to secretions of pathogenic and nonpathogenic Trichomonas vaginalis. J. Parasitol. 68: 457-462.

MANSON, P.R. and B.A. PATTERSON. 1985. Proliferative response of human lymphocytes to secretory and cellular antigens of Trichomonas vaginalis. J. Parasitol. 71(3): 265-268.

MANTOVANI, A., N. POLENTARUTTI, G. PERI, G. MARTINOTTI, and F. LANDOLFO. 1981. Cytotoxicity of human peripheral blood monocytes against Trichomonas vaginalis. Clin. Exp. Immunol. $46: 391-396$.

MARDH, P.A. 1991. The vaginal ecosystem. Amer. J.obstet.Gynecol. $165(4): 1163-1176$.

MARDH, P.A. and L.V. SOLTESZ. 1983. In-vitro interactions between Lactobacilli and other microorganisms occurring in the vaginal flora. Scand. J. Infect. Dis. Suppl. 40: 47-51.

MARTINOTTI, M.G., I. CAGLIANI, C. LATTES and P. CAPPUCCINELII. 1977. Immune responses and degree of protection in mice immunized with Trichomonas vaginalis antigen. G. Bacteriol. Virol. Immunol. 70: 3-12.

MATHEWS, H.M., and G.R. HEALY. 1983. Evaluation of two serological tests of Trichomonas vaginalis infection. $J$. Clin. Micro. $17(5)$ : 840-843.

MCGRORY T., and G.E GARBER 1992. Mouse intravaginal infection with Trichomonas vaginalis and role of Lactobacillus acidophilus in sustaining infection. Infect. Immun. $60(6)$ : 2375-2379.

MCGRORY, T. K.MEYSICK, L.T.LEMCHUK FAVEL; and G.E. GARBER 1994. The interaction of Lactobacillus acidophilus and Trichomonas vaginalis in-vitro. J.Parasitol. $80(1): 50-54$.

MCGROARTY, J.A. 1983. Probiotic use of lactobacilli in the human female urogenital tract. FEMS. Immn. and Med. Microbiol. 6: 251-264.

MCKERROW, J.H., E. SUN, P.J. ROSENTAL, and J. BOUVIER. 1993. The proteinases and pathogenicity of parasite protozoa. Ann. Rev. Microbiol. 47: 821-853.

MCLAREN, I.C., L.E. DAVIS, G.R HEADY AND C.G. JAMES, 1983. Isolation of Trichomonas vaginalis from the respiratory tract of infants with respiratory disease. Pediatrics 71: 888-890.

MEHTA, JP.V. 1982. Vaginal flora. A dynamic ecosystem. $J$. Reprod. Med. 27(8): 455-458. 
MEYSICK, K.C., and G.E. GARBER. 1992. Interactions between Trichomonas vaginalis and vaginal flora in a mouse model. $J$. Parasitol. 78(I): 157-160.

MULLER, M.1990. Biochemistry of Trichomonas vaginalis. In Trichonomonads parasitic in Humans, B.M. Honigberg (ed) Springer-Verlag, New York, p. 53-83.

NIELSEN, M.H. and R. NIELSEN. 1975. Electron microscopy of Trichomonas vaginalis. Donne: Interaction with vaginal epithelium in human trichomoniasis. Acta. Path. Microbiol. scand. Sect. B. 83: 305-320.

NEISTEIN, L.S, J.GOLDENRING., AND S.CARPENTER. 1984. NOnsexual transmission of sexually transmitted diseases: An infrequent occurence. Pediatrics. 74:67-76.

NGUMBI, P.M. and I.N. NYAKERI. 1984. Clinical experience with Solco-Trichovac in the treatment of vaginal trichomoniasis. East African Medical Journal. $61(5)$ : 372-375.

PAULSON, J.P., S. LETO and P. ASMAR. 1985. Trichomonas

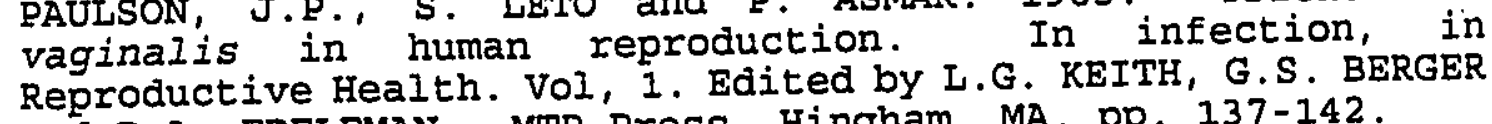
and D.A. EDELEMAN. MTP Press, Hingham, MA. pp. 137-142.

PAULT, A.G., J.V. GILBERT, and R. WINSTAR, Jr. 1977. Loss of antibody activity in human immunoglobulin exposed to extracellular immunoglobulin $A$ proteases of Neisseria gonorrhoeae and streptococcus sanguis. Infect. Immun. 17: 130-135.

PETER, J.I., R.S. DONDERO, D. KWIATROSKI, M.R. SPENCE, M.F. REIN, and J.F. ALDERETE. 1988. Monoclonal antibody-based Enzyme Iinked Immunosorbent Assay for Trichomonas vaginalis. J. Clin. Micro. 26(9): 1684-1686.

PETERSON, K.M. and J.F. ALDERETE. 1984. Iron uptake and increased intracellular enzyme activity follow host lactoferrin binding by Trichomonas vaginalis receptors. $\mathrm{J}$. Exp. Med. 160:398-410.

PROVENZANO and J.F. ALDERETE. 1995. Trichomoniasis and human Ig degradation. In Press.

REDONDO-LOPEZ, V., R.L. COOK, and J.D. SOBEL. 1990. Emerging role of Lactobacili $i$ in the control and maintenance of vaginal bacterial microflora. Rev. Infect. Dis. 12(5): 856-872.

REIN, M.F.' J.A. SULLIVAN, and G.L. MANDELL. 1980. Trichomonacidal activities of human polymorphonuclear neutrophils: killing by disruption and fragmentation. $\mathrm{J}$. 
Infect. Dis. 142: 575-585.

REIN, M.F., 1990. Clinical Manifestations of Urogenital Trichomonasis in women. In Trichomonads Parasitic in Humans, B. M. Honigberg (ed). Springer-Verlag, New York, p.225-234.

RIELY, D.E., M.C. ROBERTS, T.TAKAYAMA, and J.N. KRIEGER. 1992. Development of a polymerase chain reaction based diagnosis of Trichomonas vaginalis. J.Clin. Micro. 30(2):465-472.

ROITT IVAN.1990. The basis of immunology. In Essential Immunology, seventh edition.Blackwell Sci. Publi., p.1-14.

RUBINO, S., R. MURESA, and P. RAPPELI. 1991. Molecular probe for identification of Trichomonas vaginalis DNA. J. Clin. Microbiol. 29: 702-706.

RYU, J. S., AHN M.H., and D.Y. MIN. 1990. Cytotoxicity of resident and lymphokine activated mouse peripheral macrophage against Trichomonas vaginalis. Korean J. Parasitol. 28(2): 85-89.

SHAIO. M.F., F.Y. CHANG, S.C. HOU, C.S. LEE and P.R. LIN. 1991. The role of immunoglobulin and compliment in enhancing the respiratory burst of neutrophils against Trichomonas vaginalis. Parasite Immunology. 13: 241-250.

SHAIO, M.F., P.R. LIN, C.S. LEE, S.C. HOU, P. TANG. and K.D. YANG. 1992. A novel neutrophil-activating factor released by Trichomonas vaginalis. Infect. Immun; 60(11): 4475-4482.

SHAIO. M.F., P.R. IIN and C.S. LEE 1993. Killing of Trichomonas vaginalis by complement mediated lysis is not associated with the presence of Trichomonas vaginalis virus. Iner. J Para. 23; 675-680.

SHARMA, P., N. MALLA, I. GUPTA, N.K. GANGUZY and R.C. MAHAJAN. 1991. Anti-trichomonad IgA antibodies in trichomoniasis before and after treatment. Folia Microbiol. 36: 302-304.

SIBAU, L., D. BEBB, E.M. PROCTOR, and W.R. BOWIE. 1987. Enzyme linked immunosorbent assay for the diagnosis of trichomoniasis in women. Sex. Trans. Dis. 14(4): 216-220.

SKANGALIS, M., C.E. SWENSON, C.J. MAHONEY, and W.M. O'LEARY. 1979. The normal microbial flora of the baboon vagina. J.Med. Primatol. 8: 289-297.

SKARIN, A. and J. SYLWAN. 1986. Vaginal Lactobacilli inhibiting growth of Gardnerella vaginalis, Mobiluncus and other bacterial species cultured from vaginal content of women with bacterial vaginosis. Path. Microbio. Immunol. Scand. 
Sect. B; $94: 399-403$.

SPECK. W.T., A.B. STEIN, and H.S. ROSENKRANZ. 1976. Mutagenicity of metronidazole: presence of several active metabolites in human urine. J. Natl. Cancer Inst. 56: $283-$ 284 .

SPIEGEL, C.A. 1990. Microflora associated with Trichomonas vaginalis and vaccination against vaginal trichomoniasis. In Trichomonads parasitic in Humans, B.M. Honigberg (ed.). Springer-Verlag, New York, p. 213-224.

STREET, D.A., D. TAYLOR-ROBINSOR, J.P. ACKERS, N.F. HANNA, and A.MCMILLAN. 1982. Evaluation of an Enzyme-Linked Immunosorbent-Assay for the detection of antibody to Trichomonas vaginalis in sera and vaginal secretions. Br. J. vener. Dis. 58: 330-333.

STREET, D.A., D. TAYLOR-ROBINSON, and C.M. HETHERINGTON. 1983. Infection of female squirrel monkeys (Saimiri Sciureus) with Trichomonas vaginalis as a model of trichomoniasis in women. Br. J. Vener. Dis. 59: 249-254.

STYRT, B., B. SUGARMAN, N. MUMMAW, and J.C. WHITE. 1991. Chemorepulsion of trichomonads by products of neutrophil oxidative metabolism. J. Infect. Dis. 163(1): 176-179.

SU-IIN, K.E. 1982. Antibody to Trichomonas vaginalis in human cervico-vaginal secretions. Infect. Immun. 37: 852-857.

SU-IIN, K.E. and B.M. HONGBERG. 1983. Antigenic analysis of Trichomonas vaginalis strains by quatitative fluorescent antibody methods. Z. Parasitenkd. 69: 162-181.

TALBOT,J.A., NIELSEN, K., and L.B.CORBEIL.1991. Clevage of proteins of reproductive secretions by extra-cellular proteinases of Trichomonas foetus. Can. J. Microbiol. 37: 384-390.

THAPAR, M.A., E.L. PARR, and B.R. PARR. 1990. Secretory immune respónses in mouse vaginal fluid after pelvic, perenteral or vaginal immunization. Immun. 70: 121-125.

THOMSON, J.I., and S.M. GELBART. 1989. Trichomonas vaginalis. obstet. Gynecol. 74: 536-541.

TUTTLE, J.P. Jr., T.W. HOLBROOK, and F.C. DERRICK. 1977. Interference of human spermatozoal motility by Trichomonas vaginalis. J. Urol. 118: 1024-1025.

VOOGD, C.E., VAN DER STEL, J.J., JACOBS J.A.A. 1974. The mutagenic action of nitroimidazole. I. Metronidazole, 
nimorazole, dimetridazole and ronidazole . Mutat. Res. 26: $483-490$.

WALLIN, J.E., S.E. THOMPSON, A. ZAIDI, and K.H. WONG. 1981. Urethritis in women attending a STD clinic. Br. J. Vener. Dis. 57 : 50-54.

WHITTINGTON, J.M. 1951. The survival of Trichomonas vaginalis at various temperatures below $37^{\circ} \mathrm{C}$. J. Hyg. 49: 400-409.

WHITTINGTON, J.M. 1957. Epidemiology of infections with Trichomonas vaginalis in the light of improved diagnostic methods. Br. J. Vener Dis. 33: 80-91.

WIRA, C.R., and C.P. SANDOE. 1980. Hormonal Regulation of Immunoglobulin: Influence of Estradiol on Immunoglobulin $A$ and $G$ in the rat uterus. Endocrinology, 106(3): 1020-1026.

WIRA, C.R., and SULLIVAN, B.A 1985. Oestradiol and progestrone regulation of IgA, IgG and secretory component in cervico vaginal secretions of rat. Biol. Reprod. 32: 90-97.

WOLNER-HANSSEN， P. , KRIEGER，J.N. STEVENS, C.E.' KIVIAT, N.B., KOUTSKY, L., CRITCHLOW, C., DEROUEN, T.; HILLIER, S. , and HOLMES, K.K. 1989. Clinical Manifestations of vaginal trichomoniasis. $J$ Amer. Med. Associ. 261, 571-576.

WOS, M.S., and R.M. WATT. 1986. Immunoglobulin isotypes of anti-Trichomonas vaginalis antibodies in patients with vaginal trichomoniasis. J. Clin. Micro. 24(5): 790-795.

YANO, A., R. KAJI, S. KOJIMA, and Z. OVARY. 1982. Immune response to Trichomonas vaginalis. Int. Archs. Aller. appl. Immun. 67: 310-314.

YANO, A., K. YUI, F. AOSAI, S. KOJIMA, T. KAWANA, and $Z$. OVARY. 1983. Immune response to Trichomonas vaginalis. Int. Arch. Aller. appl. Immun. 72: 150-157.

YANO, A., F. AOSAI, K. YUI, S. KOJIAMA, and T. KAWANA. 1983. Antigen-specific proliferation responses of peripheral blood lymphocytes to Trichomonas vaginalis antigen in patients with Trichomonas vaginalis. J. Clin. Microbiol. 17: 175-180.

YOON, K., J.S. RYU and D.Y. MIN. 1991. Cytotoxicity of lymphokine activated peritoneal macrophages against Trichomonas vaginalis. Korean J. Parasitol. 29(4): 381-388.

YULE, A., MCGELLEN, J.D. ORIEL, and J.P. PACKERS. 1987. Detection of Trichomonas vaginalis antigen in women by enzyme immunoassay. J. Clin. Pathol. 40: 566-568. 


\section{APPENDIX}

\section{TYI S-33 Medium:}

Ingredients for $900 \mathrm{ml}$ of medium.

$783 \mathrm{ml} \mathrm{dd} \mathrm{H}_{2} \mathrm{O}$

Casitone or Casein digest peptone

$18.0 \mathrm{gm}$

Enzymatic digest of casein.

BBL Microbiology system.

Becton Dickinson \& co. Cockeville MD21030.

Bacto Yest Extract ("Difco" Certified)

$9.0 \mathrm{gm}$

Difco Lacboratories, Detroit, Michigen.

Dextrose (Certified A.C.S Anhydrous)

$9.0 \mathrm{gm}$

Fisher Scientific Company.

Fair Lawn, New Jersey 07410

Sodium Chloride. (Anala R Grade)

$1.8 \mathrm{gm}$

BDi Chemicals Vancouver.

Potassium Phosphate Monobasic (A.C.S)

$0.54 \mathrm{gm}$

Fisher Scientific Company

Fair Lawn, New Jersey 07410

Potassium Phosphate Dibasic Anhydrous (A.C.S)

$0.9 \mathrm{gm}$

Fisher Scientific Company.

Fair Lawn, New Jersey 07410

L. Cysteine HCL. $\mathrm{H}_{2} \mathrm{O}, \mathrm{N} . \mathrm{R} . \mathrm{C}$

Grand Island Biological Comapany (GIBCO)

$0.9 \mathrm{gm}$

Grand Island NY 14072

I.Ascorbic Acid (Vit.C)

$0.18 \mathrm{gm}$

BDH Chemical Vancouver.

Ferric Ammonium Citrate

$0.02052 \mathrm{gm}$

Mallinckrodt, Inc.

St.Louis Missouri 63147

$\mathrm{pH}$ to 6.2

Autoclave.

Vitamin Tween

NCT 109 (\#320-1340)

$0.1 \mathrm{ml}$ Tween $80+130 \mathrm{ml}$ NCT $109 \mathrm{Vit}$. 
Citrate Buffer:

Citric acid (Fisher)

$1.11 \mathrm{~g}$

$\mathrm{Na}_{2} \mathrm{HPO}_{4}$ (BDH)

dd $\mathrm{H}_{2} \mathrm{O}$

$0.117 \mathrm{~g}$

$80 \mathrm{ml}$

$\mathrm{pH}$ to 4.25 exactly with $1 \mathrm{M} \mathrm{NaOH}$ then dilute

to $100 \mathrm{ml}$ with dd $\mathrm{H}_{2} \mathrm{O}$.

Substrate Solution for EIA:

Citrate Buffer

$10 \mathrm{ml}$

$20 \mathrm{ul}$

$\mathrm{H}_{2} \mathrm{O}_{2}$

ABTS

$4 \mathrm{mg}$

dd $\mathrm{H}_{2} \mathrm{O}$

$10 \mathrm{mI}$ 